\title{
Overview of the Manitou Experimental Forest Observatory: site description and selected science results from 2008 to 2013
}

\author{
J. Ortega ${ }^{1}$, A. Turnipseed ${ }^{1}$, A. B. Guenther ${ }^{1, \mathrm{a}}$, T. G. Karl ${ }^{1, \mathrm{~b}}$, D. A. Day ${ }^{2}$, D. Gochis ${ }^{1}$, J. A. Huffman ${ }^{3,4}$, A. J. Prenni ${ }^{5, \mathrm{c}}$, \\ E. J. T. Levin ${ }^{5}$, S. M. Kreidenweis ${ }^{5}$, P. J. DeMott ${ }^{5}$, Y. Tobo ${ }^{5, \mathrm{~d}}$, E. G. Patton ${ }^{1}$, A. Hodzic ${ }^{1}$, Y. Y. Cui ${ }^{6}$, P. C. Harley ${ }^{1, \mathrm{e}}$, \\ R. S. Hornbrook ${ }^{1}$, E. C. Apel ${ }^{1}$, R. K. Monson ${ }^{7}$, A. S. D. Eller ${ }^{8, f}$, J. P. Greenberg ${ }^{1}$, M. C. Barth ${ }^{1}$, P. Campuzano-Jost ${ }^{2}$, \\ B. B. Palm ${ }^{2}$, J. L. Jimenez ${ }^{2}$, A. C. Aiken ${ }^{9}$, M. K. Dubey ${ }^{9}$, C. Geron ${ }^{10}$, J. Offenberg ${ }^{11}$, M. G. Ryan ${ }^{12,13}$, P. J. Fornwalt ${ }^{13}$, \\ S. C. Pryor ${ }^{14, g}$, F. N. Keutsch ${ }^{15}$, J. P. DiGangi ${ }^{15, \mathrm{~h}}$, A. W. H. Chan ${ }^{16, \mathrm{i}}$, A. H. Goldstein ${ }^{16,17}$, G. M. Wolfe ${ }^{18,19}$, S. Kim ${ }^{1, j}$, \\ L. Kaser ${ }^{20, k}$, R. Schnitzhofer ${ }^{20}$, A. Hansel ${ }^{20}$, C. A. Cantrell ${ }^{1,1}$, R. L. Mauldin ${ }^{1,1}$, and J. N. Smith ${ }^{1,21}$ \\ ${ }^{1}$ National Center for Atmospheric Research, P.O. Box 3000, Boulder, CO 80307, USA \\ ${ }^{2}$ University of Colorado, Department of Chemistry and Biochemistry and CIRES, Boulder, CO 80309, USA \\ ${ }^{3}$ Max Planck Institute for Chemistry, P.O. Box 3060, 55020, Mainz, Germany \\ ${ }^{4}$ University of Denver, Department of Chemistry \& Biochemistry, Denver, CO 80208, USA \\ ${ }^{5}$ Department of Atmospheric Science, Colorado State University, Fort Collins, CO 80523, USA \\ ${ }^{6}$ Department of Earth and Atmospheric Sciences, Saint Louis University, MO 63103, USA \\ ${ }^{7}$ School of Natural Resources and the Environment and Laboratory for Tree Ring Research, University of Arizona, Tucson, \\ AZ 85721, USA \\ ${ }^{8}$ Cooperative Institute for Research in Environmental Sciences (CIRES), University of Colorado, Boulder, CO 80309, USA \\ ${ }^{9}$ Los Alamos National Laboratory, Earth and Environmental Sciences Division, Los Alamos, NM 87545, USA \\ ${ }^{10}$ US Environmental Protection Agency, Office of Research and Development, National Risk Management Research \\ Laboratory, Air pollution Prevention and Control Division, Research Triangle Park, NC 27711, USA \\ ${ }^{11}$ United States Environmental Protection Agency, Office of Research and Development, National Exposure Research \\ Laboratory, Research Triangle Park, NC 27711, USA \\ ${ }^{12}$ National Resource Ecology Laboratory, Colorado State University, Fort Collins, CO 80523, USA \\ ${ }^{13}$ United States Department of Agriculture, Forest Service, Rocky Mountain Research Station, 240 West Prospect Rd., Fort \\ Collins, CO 80526, USA \\ ${ }^{14}$ Department of Geological Sciences, Indiana University, Bloomington IN 47405, USA \\ ${ }^{15}$ Department of Chemistry, University of Wisconsin, Madison, WI 53706, USA \\ ${ }^{16}$ Department of Environmental Science, Policy and Management, University of California, Berkeley, CA 94720, USA \\ ${ }^{17}$ Department of Civil and Environmental Engineering, University of California, Berkeley, CA 94720, USA \\ ${ }^{18}$ Atmospheric Chemistry and Dynamics Laboratory, Goddard Space Flight Center, 8800 Greenbelt Road, Greenbelt, \\ MD 20771, USA \\ ${ }^{19}$ Joint Center for Earth Systems Technology, University of Maryland Baltimore County, Baltimore County, MD 21250, USA \\ ${ }^{20}$ Institute for Ion Physics and Applied Physics, University of Innsbruck, Innsbruck, Austria \\ ${ }^{21}$ Department of Applied Physics, University of Eastern Finland, 70211 Kuopio, Finland \\ a now at: Pacific Northwest National Laboratory, Atmospheric Sciences Division, P.O. Box 999 Richland, WA 99352, USA \\ ${ }^{b}$ now at: University of Innsbruck, Institute for Meteorology and Geophysics (IMGI), Innrain 52, 6020 Innsbruck, Austria \\ ${ }^{c}$ now at: Air Resources Division, National Park Service, Lakewood, CO 80225, USA \\ dnow at: National Institute of Polar Research, Tachikawa, Tokyo 190-8518, Japan \\ ${ }^{e}$ now at: Department of Plant Physiology, Estonian University of Life Sciences, Tartu 51014, Estonia \\ ${ }^{f}$ now at: Department of Biological Sciences, Macquarie University, Sydney, NSW 2109, Australia

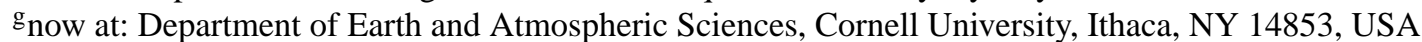 \\ ${ }^{\mathrm{h}}$ now at: NASA Langley Research Center, Chemistry and Dynamics Branch, Hampton, VA 23681, USA \\ ${ }^{i}$ now at: Department of Chemical Engineering and Applied Chemistry, University of Toronto, Canada

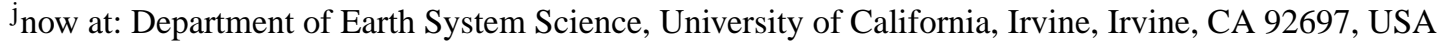 \\ ${ }^{k}$ now at: National Center for Atmospheric Research, P.O. Box 3000, Boulder, CO 80307, USA \\ ${ }^{1}$ now at: Department of Atmospheric and Oceanic Sciences, University of Colorado, Boulder, CO 80309, USA
}


Correspondence to: J. N. Smith (jimsmith@ucar.edu)

Received: 23 November 2013 - Published in Atmos. Chem. Phys. Discuss.: 20 January 2014

Revised: 30 April 2014 - Accepted: 12 May 2014 - Published: 26 June 2014

\begin{abstract}
The Bio-hydro-atmosphere interactions of Energy, Aerosols, Carbon, $\mathrm{H}_{2} \mathrm{O}$, Organics \& Nitrogen (BEA$\mathrm{CHON}$ ) project seeks to understand the feedbacks and interrelationships between hydrology, biogenic emissions, carbon assimilation, aerosol properties, clouds and associated feedbacks within water-limited ecosystems. The Manitou Experimental Forest Observatory (MEFO) was established in 2008 by the National Center for Atmospheric Research to address many of the BEACHON research objectives, and it now provides a fixed field site with significant infrastructure. MEFO is a mountainous, semi-arid ponderosa pine-dominated forest site that is normally dominated by clean continental air but is periodically influenced by anthropogenic sources from Colorado Front Range cities. This article summarizes the past and ongoing research activities at the site, and highlights some of the significant findings that have resulted from these measurements. These activities include
\end{abstract}

- soil property measurements;

- hydrological studies;

- measurements of high-frequency turbulence parameters;

- eddy covariance flux measurements of water, energy, aerosols and carbon dioxide through the canopy;

- determination of biogenic and anthropogenic volatile organic compound emissions and their influence on regional atmospheric chemistry;

- aerosol number and mass distributions;

- chemical speciation of aerosol particles;

- characterization of ice and cloud condensation nuclei;

- trace gas measurements; and

- model simulations using coupled chemistry and meteorology.

In addition to various long-term continuous measurements, three focused measurement campaigns with state-of-the-art instrumentation have taken place since the site was established, and two of these studies are the subjects of this special issue: BEACHON-ROCS (Rocky Mountain Organic Carbon Study, 2010) and BEACHON-RoMBAS (Rocky Mountain Biogenic Aerosol Study, 2011).

\section{Introduction}

\subsection{Motivation}

Development of Earth system models is driven by the need to improve the predictability of atmospheric chemical and physical processes over timescales ranging from minutes to decades. Accurate model predictions are contingent on process-level understanding and detailed numerical descriptions of the coupling between water, energy and biogeochemical cycles across temporal and spatial scales (Denman et al., 2007; Alo and Wang, 2008; Heald et al., 2009). A number of studies have discussed some of these processes and associated feedbacks (e.g., Barth et al., 2005; Carslaw et al., 2010; Mahowald et al., 2011), but more detailed observations and coordinated modeling efforts are required for improved representation in Earth system models.

The Bio-hydro-atmosphere interactions of Energy, Aerosols, Carbon, $\mathrm{H}_{2} \mathrm{O}$, Organics \& Nitrogen (BEACHON) project was initiated by the National Center for Atmospheric Research (NCAR) as well as research collaborators from the university community to investigate ecosystem-atmosphere exchange of trace gases and aerosols and their potential feedbacks between biogeochemical and water cycles. BEACHON is now an ongoing component of atmospheric research sponsored by the National Science Foundation. This interdisciplinary research program integrates local and regional model simulations with remote sensing, regional network observations, and canopy- to regional-scale field measurements. BEACHON includes investigations of atmospheric, ecological and hydrological processes including concentration and flux measurements of energy, $\mathrm{CO}_{2}$, $\mathrm{H}_{2} \mathrm{O}$, volatile organic compounds, aerosols, nitrogen compounds, hydrological parameters and feedback processes that are relevant to atmospheric chemistry. Rocky Mountain ecosystems are important for providing water and other resources in the western United States, but contain only a limited number of long-term monitoring sites. This region is predominantly arid or semi-arid, resulting in biogeochemical cycles that are water limited. Since the area contains some of the fastest growing population centers, water limitations (combined with a climate that is projected to be warmer and potentially drier) pose significant societal vulnerabilities (Vorosmarty et al., 2010). The region's remote complex terrain leads to highly variable ecosystem characteristics, and it is unclear how this variability affects hydrological and atmospheric processes across larger geographical areas. The need for long-term land-ecosystem-atmosphere observation 
networks has been identified by international research programs as a key need for advancing Earth system science (Guenther et al., 2011).

To address these challenges, the BEACHON project in collaboration with the United States Department of Agriculture (USDA) Forest Service established the Manitou Experimental Forest Observatory (MEFO) in 2008, in an area representative of a middle-elevation ( 2000-2500 m a.s.l.), semiarid, ponderosa pine ecosystem that is common throughout the Rocky Mountain West, but not adequately characterized. The BEACHON project and establishment of this site were designed to meet the following objectives:

- collect long-term measurements of meteorology, water, carbon dioxide $\left(\mathrm{CO}_{2}\right)$, energy fluxes, aerosol size distributions and fluxes, trace gas and cloud condensation nuclei concentrations;

- monitor soil moisture, precipitation, snowpack, stable water isotopes, and other hydrological variables to provide input and lateral boundary conditions for Earth system models and as a basis for making more accurate water resource predictions for this and other semi-arid regions;

- provide infrastructure for collaborative research among government laboratories, universities and private companies;

- carry out intensive measurement campaigns;

- provide training for undergraduate and graduate students and promote multidisciplinary research.

This article describes the Manitou Experimental Forest Observatory, presents ongoing research at the site and highlights some initial findings. More specific scientific results and publications can be found in the publication list (Table S2 in the Supplement) and within the individual articles as part of this special issue of Atmospheric Chemistry and Physics.

\subsection{Site description and meteorological overview}

The Manitou Experimental Forest $\left(39.1006^{\circ} \mathrm{N}\right.$, $105.0942^{\circ} \mathrm{W}$; Fig. 1a, b), in the Front Range of the Colorado Rocky Mountains, has been managed as a research facility by the USDA Forest Service's Rocky Mountain Research Station since 1938. It contains approximately 6760 ha and exemplifies the Colorado Front Range wildland-urban interface, where semi-arid montane forest ecosystems are in close proximity to larger urban centers. These interface areas, which also contain a number of small residential communities, are prone to wild fires from lightning as well as human causes. Two particularly large nearby fires (the $560 \mathrm{~km}^{2}$ Hayman fire in 2002 and the $74 \mathrm{~km}^{2}$ Waldo Canyon fire in 2012) were among the most ecologically and economically damaging in the state's history. Although the primary study areas were not burned, areas within several kilometers to the south and west of the site were affected by the 2002 fire. The landscape has thus been dramatically affected in both appearance and in the vegetation's ability to slow soil erosion from surface runoff during monsoon rains. Fire-damaged portions of the forest can change aspects of the atmospheric chemistry measured at the site through changes in gas- and aerosol-phase emissions from nearby fire-scarred vegetation and soil. Wildfires are ubiquitous in the semi-arid forested American West, of which this area can be considered representative.

This forest's elevation ranges from 2280 to $2840 \mathrm{~m}$ a.s.l., and vegetation is primarily composed of forests of ponderosa pine, Douglas fir, mixed conifer and aspen. The forest stands surrounding the observatory are relatively young, unevenaged stands dominated by ponderosa pine. In 2009, core samples from a survey of 38 representative ponderosa pine showed that the median tree age was 49.5 years (with average, minimum and maximum ages of 62.5, 27 and 201 years, respectively).

Soils underlying the tower site and the surrounding area are classified as deep, well-drained sandy loams and sandy gravelly loams originating from alluvial deposits weathered from underlying arkosic sandstone formations as well as nearby granite formations (Soil Conservation Service, 1992). Although numerous outcroppings of partially weathered sandstone exist around the site, the average depth to bedrock is estimated to be between 1 and $1.8 \mathrm{~m}$ (36-60 in) below ground surface. The soil ranges from slightly acidic to moderately alkaline ( $\mathrm{pH}$ 6.1-7.8) with little organic matter content (1-4\%) and rooting depths reported to be in excess of $1.3 \mathrm{~m}$ (40 in). Soil permeability on undisturbed soils is moderately rapid (approx. $50-150 \mathrm{~mm} \mathrm{~h}^{-1}$ ). Rapid runoff and sediment transport occurs on compacted road surfaces and other areas void of significant ground vegetation. The tower site is on an alluvial bench, formed by the erosion of underlying granite. It is situated in a broad, shallow valley approximately $1 \mathrm{~km}$ west of an intermittent creek, which flows towards the north. The terrain slope is asymmetric across this valley with the east side of the valley being steeper and the west side being more gradual (gradient between 3 and $8 \%$ ).

The National Weather Service has been monitoring precipitation at MEFO since 1940 (Station Woodland Park 8 NNW, Coop ID: 059210), and US Forest Service staff have been collecting meteorological data including air and soil temperature, precipitation and wind speed since 1998. The climate is cool (mean temperature is $19^{\circ} \mathrm{C}$ in July and $-2{ }^{\circ} \mathrm{C}$ in January) and dry with an average annual precipitation for 2010-2013 of $430.5 \mathrm{~mm}$ (16.94 in). Approximately $50 \%$ of the precipitation falls as rain during the summer season (June-September), primarily during afternoon thunderstorms characterized by brief but intense periods of rainfall and lightning. Winter snowfall is typically light, and a persistent snowpack rarely develops. 


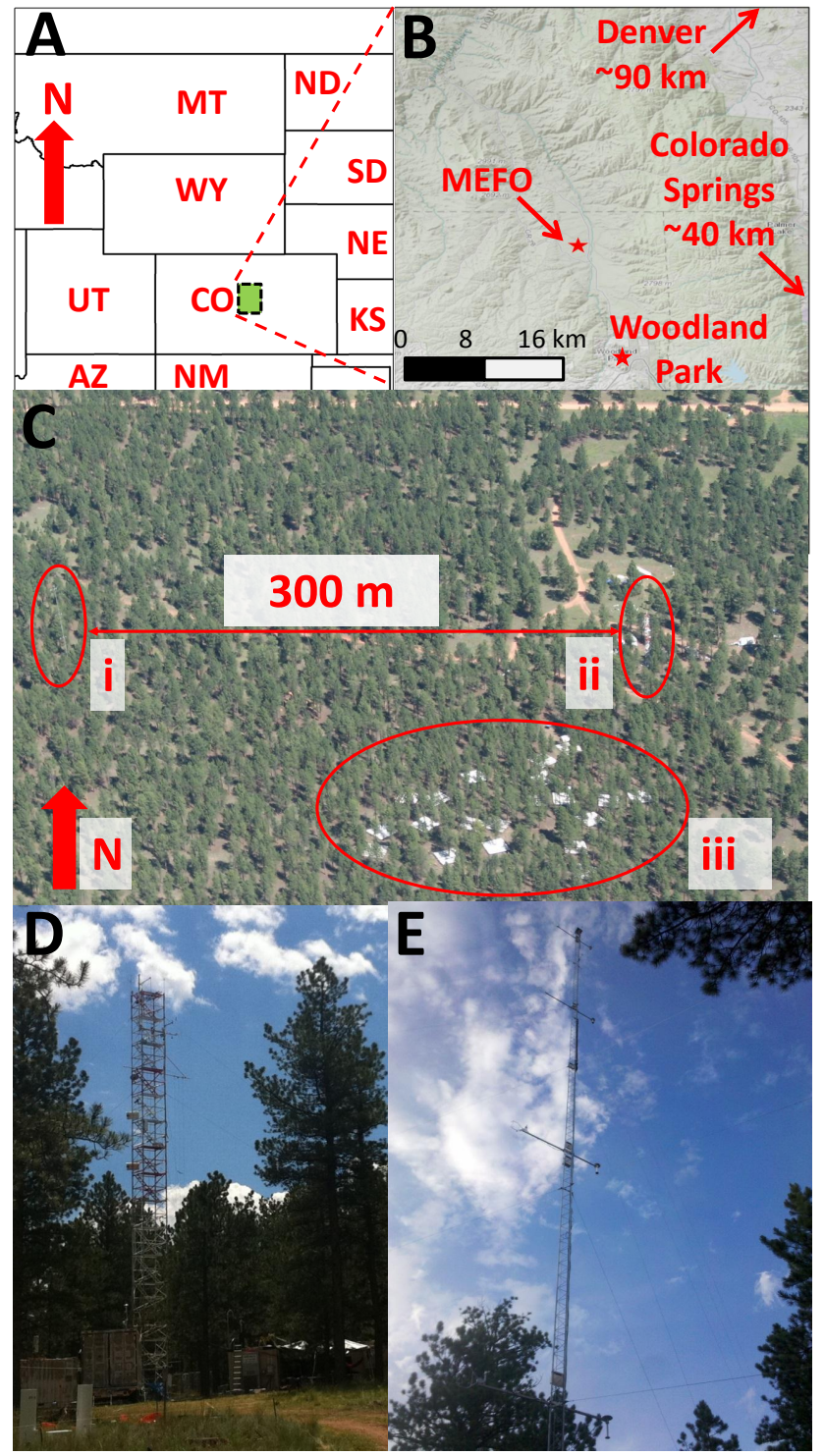

Figure 1. Manitou Experimental Forest Observatory (MEFO). (A) Map showing general area within Colorado and its relationship to neighboring states. (B) Site location relative to the Front Range urban corridor including Denver and Colorado Springs. (C) Closeup aerial photograph showing the open-canopy ponderosa pinedominated forest with the (i) micrometeorological tower, (ii) chemistry tower and (iii) water manipulation experiment. (D) Close-up picture of the chemistry tower. (E) Close-up picture of micrometeorological tower. The two towers shown in $\mathrm{C}$ are approximately $300 \mathrm{~m}$ apart. Maps in (A) and (B) were produced using ArcGIS software (ESRI Inc., Redlands, CA).

Like much of Colorado, the site has a high frequency of sunny days during most of the year. During midday in July 2011, approximately $90 \%$ of the days had PAR values (photosynthetically active radiation between 400 and $700 \mathrm{~nm}$ ) above the canopy that exceeded $2100 \mu \mathrm{mol} \mathrm{m}^{-2} \mathrm{~s}^{-1}$, and part of every day reached a PAR value of at least
$2000 \mu \mathrm{mol} \mathrm{m} \mathrm{m}^{-2} \mathrm{~s}^{-1}$. Frequent afternoon thunderstorms can temporarily reduce the solar insolation, but rarely for more than $3 \mathrm{~h}$. Figure 2 shows the diel cycles of net longwave and shortwave radiation, latent heat flux, sensible heat flux and net $\mathrm{CO}_{2}$ flux (calculated using the eddy covariance method) from four representative months during 2011. Each point represents the $30 \mathrm{~min}$ average for that time period. The net radiation is calculated from the difference between the downwelling radiation and the upwelling radiation from the radiometers at the top $(28 \mathrm{~m})$ of the chemistry tower. It is interesting to note the net carbon uptake in the spring (April) and autumn (October) during the day, and the large nighttime respiration flux in July.

Numerous studies have been conducted here by researchers from a wide range of federal agencies, academic institutions and non-governmental organizations. Early research focused on range management, including revegetation of abandoned fields, grazing management in native and seeded pastures, watershed management in gully control, stream sedimentation, surface runoff, bacterial pollution and infiltration (Gary et al., 1985). Recent research is more diverse, and includes a long-term ( $>30$ years) study on the flammulated owl (Linkhart et al., 2006, 2007), studies assessing the impacts of forest restoration and fuel reduction techniques (Battaglia et al., 2010; Massman et al., 2010; Rhoades et al., 2012), silviculture studies (Lezberg et al., 2008) and wildfire recovery studies (Fornwalt et al., 2010). Additional information about the site (including long-term weather, tree growth data and a bibliography of publications) can be found at http://www.fs.usda.gov/manitou.

\subsection{Measurements at the Manitou Experimental Forest Observatory (MEFO) under the auspices of BEACHON}

In 2008, with cooperation with the USDA Forest Service, NCAR established the infrastructure at the site and named it the Manitou Experimental Forest Observatory (MEFO). The site includes four mobile steel containers each having $14.9 \mathrm{~m}^{2}$ of laboratory floor space, numerous sampling ports, temperature control and $20 \mathrm{~kW}$ power. Two research towers that extend through the canopy were constructed approximately $300 \mathrm{~m}$ apart (Fig. 1c) and are referred to here as the micrometeorology and chemistry towers. Detailed information on these towers' measurements is listed in Table S1 in the Supplement. A third (smaller) eddy covariance measurement tower was deployed in a large clearing or "forest gap" from 2011 to 2012. The purpose of this smaller tower was to make four-way radiation measurements, surface skin temperature, and sensible and latent heat flux measurements over the grass and forb vegetation that is found beneath and in between the ponderosa pine. These measurements were taken at 1 and $3 \mathrm{~m}$ above ground level.

The micrometeorology tower (Fig. 1e) is a narrow $45 \mathrm{~m}$ triangular tower (Rohn Products, Peroria, IL, USA; model 

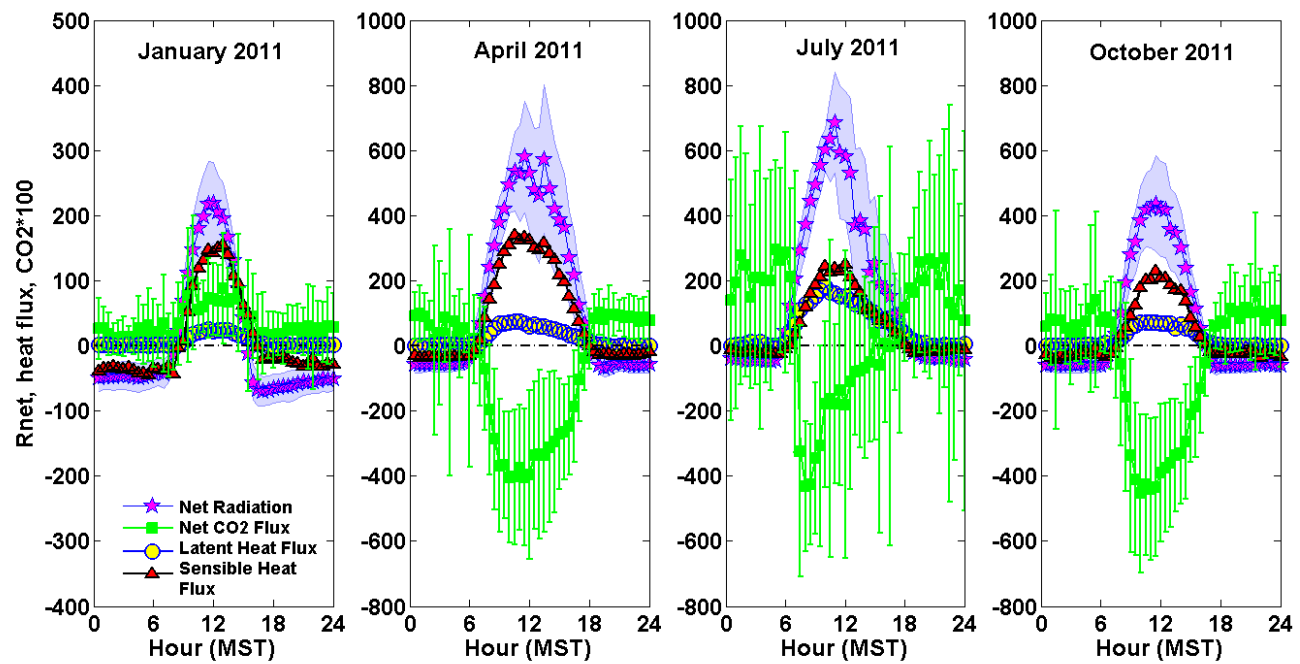

Figure 2. Average diel net radiation (downwelling minus upwelling), latent heat flux, sensible heat flux and net $\mathrm{CO}_{2}$ flux for four representative months. All properties were measured from $28 \mathrm{~m}$ at the top of the chemistry tower in 2011 . Each data point represents a 30 min average for that time period. The $y$ axis limits are the same for each plot except for January, where the scale is $1 / 2$ of the other three months. The shaded area for net radiation and error bars for $\mathrm{CO}_{2}$ flux represent \pm 1 standard deviation. Error bars for sensible and latent heat fluxes have been omitted for clarity.

45G; $425 \mathrm{~mm}$ per side) designed to facilitate the analysis of the impact of canopy elements (needles, branches, trunks) on turbulent exchange between the surface, canopy layers and the overlying atmosphere. The instruments on the micrometeorology tower operated nearly continuously from July 2009 until July 2012, when they were removed as a precaution due the proximity of the Waldo Canyon fire. This tower had instruments deployed at six different levels $(2,8,16,22,30$ and $43 \mathrm{~m}$ ), thus allowing several measurements within and above the canopy (average canopy height $\approx 16 \mathrm{~m}$ ). The $22 \mathrm{~m}$ level contained a four-component radiometer (Kipp and Zonen, the Netherlands, model CNR1) for measuring abovecanopy incoming and outgoing shortwave and longwave radiation. Instrumentation on the other five levels included

- sonic anemometers (Campbell Scientific, Logan, UT, model CSAT3) to record the three orthogonal wind velocity components and temperature fluctuations;

- NCAR-Vaisala (Vantaa, Finland) aspirated hygrothermometers to measure absolute temperature and relative humidity;

- open-path infrared gas analyzers (LiCOR, Lincoln, NE, model 7500) to measure water vapor and carbon dioxide.

This multiseason data set is being used to

- quantify the importance of canopy-induced modifications to turbulence in predicting whole-ecosystem exchange in regional and global climate models,

- partition water fluxes into transpiration and evaporation components, and
- investigate impacts of spatially heterogeneous canopy distributions on evapotranspiration using additional information from the chemistry and understory towers.

The chemistry tower is a $28 \mathrm{~m}$ walk-up-type tower that is equipped with meteorological sensors as well as a variety of flux and gradient concentration measurements for gases and aerosols (Fig. 1d). The platform on each level is $1.78 \mathrm{~m} \times 1.27 \mathrm{~m}$ and is suitable for heavier instruments that require more space, power and maintenance. It can also support gradient sampling systems, which can move vertically along the tower. This tower is also equipped with 2-D and 3-D sonic anemometers as well as temperature and radiation probes for continuous meteorological measurements and for calculating fluxes using the closed-path eddy covariance method. Other continuous gas-phase measurements from this tower have included $\mathrm{CO}, \mathrm{CO}_{2}, \mathrm{H}_{2} \mathrm{O}$ vapor, $\mathrm{NO}, \mathrm{NO}_{2}$ and $\mathrm{SO}_{2}$. The Waldo Canyon fire in June 2012 forced the removal of the trace gas instruments from the chemistry tower and all of the instruments from the micrometeorological tower. Fortunately, the fire did not directly affect the site, and meteorological measurements from the chemistry tower have operated continuously (see Table S1 in the Supplement). Since the two towers had generated 3-4 years of data and some of the instruments were required for other projects and field sites, it was decided to adjust the sampling strategy. Future core measurements of trace gases $\left(\mathrm{CO}, \mathrm{O} 3, \mathrm{SO} 2, \mathrm{NO}_{\mathrm{x}}\right)$ and aerosol number size distributions will be operated four times per year (for 4-6 weeks in duration) to capture the seasonal variability of these key species.

The suitability of these towers for making eddy covariance flux measurements in the surrounding landscape was 
analyzed by Kaser et al. (2013b). Briefly, the flux footprint was found to extend to $900 \mathrm{~m}$ for unstable boundary layer conditions and to $2500 \mathrm{~m}$ for stable conditions. However, because there is more heterogeneity in the forest composition and proximity to former burn areas inside the $2500 \mathrm{~m}$ radius, a practical limit of $1850 \mathrm{~m}$ beyond the tower was used as one of the criteria for valid flux data. A paved road $\sim 500 \mathrm{~m}$ east of the tower site caused data to be eliminated if wind direction was from that sector.

The only significant woody vegetation around the observatory is ponderosa pine. Measurements from this species include leaf- and branch-level photosynthesis, respiration and biogenic volatile organic compound (BVOC) emissions as well as sap flow using the compensation heat pulse method as described by Burgess et al. (2001). Leaf-level gas exchange was measured during maximum photosynthesis (08:00-13:00 MST) on sunlit needles $\sim 10 \mathrm{~m}$ above the ground (Table 1). Each measurement was made on 6-10 mature needles, which were defined as needles that been on the branch through at least one winter. Gas exchange measurements were made using an LI-6400 portable gas exchange system (LI-COR Biosciences, Lincoln, NE) and photosynthesis, stomatal conductance and transpiration calculations were made using total leaf area (measurement as described in Eller et al., 2013). The effects of high solar insolation, warm temperatures and low humidity just prior to monsoon precipitation are demonstrated by the low stomatal conductance and photosynthesis values in July (Table 1).

A suite of hydrological measurements for total precipitation, soil moisture, leaf wetness and snow depth have been measured nearly continuously since 2009 . Aerosol measurements include 2 years (February 2010 to January 2012) of particle size distributions from $4 \mathrm{~nm}$ to $2.5 \mu \mathrm{m}$ and 1 year of CCN (cloud condensation nuclei) data during March 2010 to April 2011 measured from one of the four mobile laboratories adjacent to the tower (Fig. 1d). An additional month of CCN measurements (May 2011) was made above the canopy ( $25 \mathrm{~m}$ above ground) from the chemistry tower (Levin et al., 2012). BEACHON-ROCS (Rocky Mountain Organics Study, 2010) and BEACHON-RoMBAS (Rocky Mountain Biogenic Aerosol Study, 2011) were two large intensive measurement campaigns that occurred at the site. Selected results from these two campaigns as well as the initial 2008 Southern Rocky Mountain (SRM) study are discussed in this article and are summarized in Sect. 5. A more detailed summary of measurements at MEFO can be found in Table S1 in the Supplement. Campaign data and long-term observations are available at the following website:

http://www2.acd.ucar.edu/campaigns.

Other long-term data are available upon request from the corresponding author.

\subsection{Meteorology at Manitou Experimental Forest Observatory}

As mentioned in Sect. 1.2, the observatory lies within a north-south drainage (draining to the north), leading to the formation of diurnal mountain-valley flows. Nighttime flow above the canopy $(28 \mathrm{~m})$ is dominated by drainage from the south as can be seen in Fig. 3b and f. Winds below the canopy are often westerly or southwesterly due to drainage flow from surrounding ridgelines (Fig. 3d). This height-dependent nocturnal pattern is dominant in all seasons. Daytime wind directions are much more variable. Although there is often a southerly flow during the day, other wind directions are also prevalent. Synoptic winter winds lead to a higher frequency of westerly and southwesterly flow (Fig. 3a and e). These conditions tend to bring relatively unpolluted air to the site from the west. Stagnant high-pressure conditions lead to locally induced upslope flow from either the northeast or southeast, which are consistently observed during daylight hours (Fig. 3c). These periods are important in understanding the local chemistry as these flows transport air from Front Range cities (mainly Denver and Colorado Springs). Regardless of the daytime wind patterns, southerly drainage flow usually develops soon after the stable nocturnal boundary layer develops, which is often accompanied by an increase in anthropogenic pollutants. Wind measurements as well as modeling results suggest that this is often due to air from the Denver area during daytime upslope flow, which then drains towards the north and past the site at night.

\section{Footprint hydrology in a water-limited ecosystem}

\subsection{Overview of hydrological measurements}

Intensive hydrological measurements of total precipitation (rain and snow), soil moisture and snow depth as well as soil temperatures have been collected at MEFO since the summer of 2009. These complement the vertical flux measurements of water vapor for a complete accounting of the site's water budget. The precipitation measurements also augment the long-term records maintained by the USDA Forest Service mentioned in Sect. 1.2. A network of 11 tipping bucket rain gauges as well as an alter-shielded, weighing-type total precipitation gauge provide high time resolution, yearround precipitation measurements in a network distributed within the chemistry tower flux footprint in order to characterize the high spatial variability of precipitation. More details about these measurements are given in Table $\mathrm{S} 1$ in the Supplement. The 2010-2013 annual accumulation of hourly precipitation is shown in Fig. 4a. These time series are biascorrected merged data products between the site's sensors in order to cover periodic data gaps. The site's annual precipitation measurements for a given year are defined by an end date of 30 September of that year and a start date of 1 
Table 1. Mean values for needle-level gas exchange measured on mature Pinus ponderosa needles at the Manitou Experimental Forest Observatory. All calculations are based on total, rather than projected, leaf area. Values in parentheses give the range of measurement dates (2011 day of year). Standard deviations are given in italics $(n=3)$.

\begin{tabular}{lrrrr}
\hline & $\begin{array}{r}\text { May } \\
(136-149)\end{array}$ & $\begin{array}{r}\text { June, July } \\
(178-185)\end{array}$ & $\begin{array}{r}\text { August } \\
(230-233)\end{array}$ & $\begin{array}{r}\text { September } \\
(263-265)\end{array}$ \\
\hline Net photosynthesis (A) & 2.9 & 0.9 & 3.2 & 3.5 \\
$\left(\mu \mathrm{mol} \mathrm{CO} \mathrm{m}^{-2} \mathrm{~s}^{-1}\right)$ & 0.6 & 0.6 & 0.8 & 0.2 \\
Stomatal conductance $\left(g_{\mathrm{s}}\right)$ & 28 & 7 & 29 & 30 \\
$\left(\mathrm{mmol} \mathrm{H}_{2} \mathrm{O} \mathrm{m}^{-2} \mathrm{~s}^{-1}\right)$ & 9 & 5 & 12 & 6 \\
Transpiration & 0.49 & 0.35 & 1.00 & 0.64 \\
$\left(\mathrm{mmol} \mathrm{H}_{2} \mathrm{O} \mathrm{m}^{-2} \mathrm{~s}^{-1}\right)$ & 0.13 & 0.28 & 0.22 & 0.07 \\
\hline
\end{tabular}
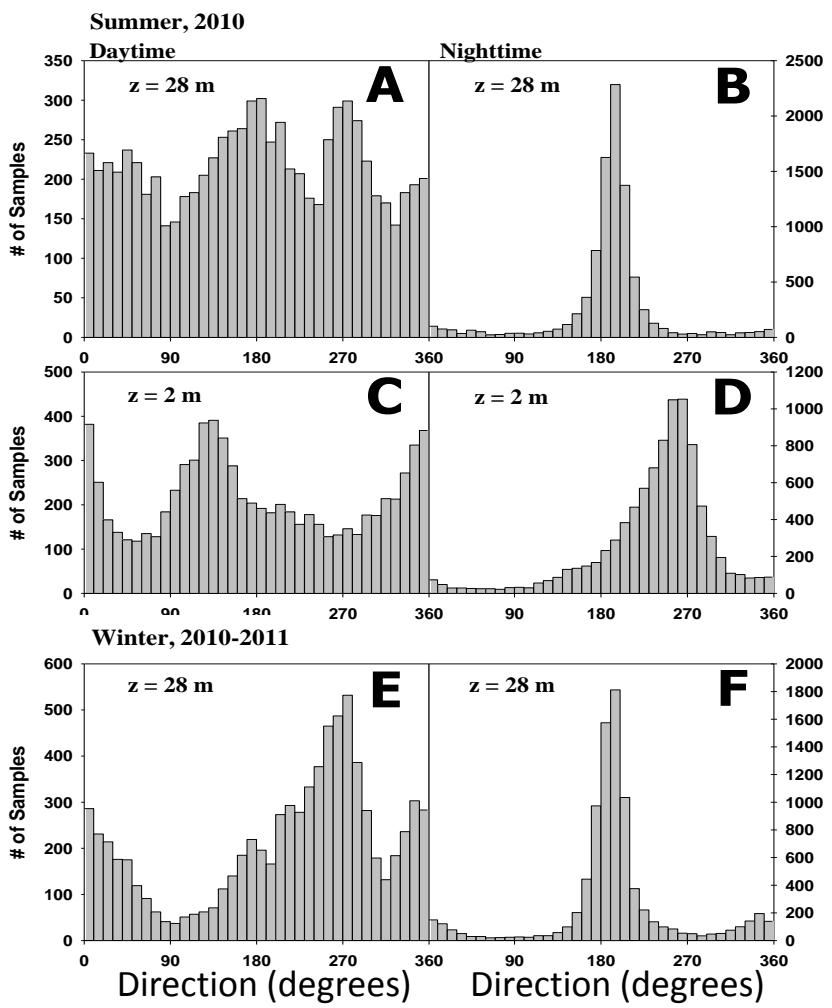

Figure 3. Wind direction distributions ( 5 min averages binned every $\left.10^{\circ}\right)$ from the MEFO chemistry tower. (a, c and e) are daytime wind distributions (09:00-17:00 MST), whereas panels (b, d and f) are for nighttime hours (20:00 until 05:00 MST). Summer includes data from June to August 2010. Winter includes data from December 2010 to February 2011. Measurement height is noted on the panels.

October in the preceding year. The patterns observed have been fairly consistent. Periodic precipitation episodes occur throughout the principal cool season of October through May followed by a brief dry season from late May through midJune. This is followed by a summer period of rather intense precipitation episodes associated with the regional incursion of the North American monsoon system. Finally, there is an extended dry period starting in late summer and extending into early autumn. The average annual accumulated precipitation for 2010-2013 was $430.5 \mathrm{~mm}$, with a range of $392 \mathrm{~mm}$ (in 2012) to $513 \mathrm{~mm}$ (in 2010). It should be noted that 2012 was among the driest years on record for most of Colorado, and the total precipitation for 2013 was similarly low. The latter year began with very low winter and spring snowfall, and stayed much drier than average until heavy September rains increased the total accumulated precipitation to about the same level observed in 2012. The maximum observed hourly rainfall recorded at the site from 2009 to 2013 was $57.9 \mathrm{~mm}$, which occurred on 4 August 2010. Other thunderstorms with high rainfall rates (up to $25 \mathrm{~mm}$ per hour) are common during the summer monsoon.

Seasonally transient snowpack is an important feature of the hydrologic cycle as the snowpack can provide a lasting water source to the site during the spring melt period and can also insulate the soil from freezing temperatures. Snow depth measurements (Jenoptik Inc., Jena, Germany, model SHM30 laser snow depth sensor) began during the winter of 2010 2011. Persistent patchy or complete snowpack is limited to December, January and February. Periodic snowstorms may also input appreciable moisture during the months of October, November, March and April, although a snowpack rarely persists for more than 7 days.

Soil moisture probes (Decagon Devices, Pullman, WA, USA, model EC-5) and temperature profiles (Campbell Scientific, Logan, UT, USA, model T107 thermistors) extending from the near surface to approximately $1 \mathrm{~m}$ depth are made at three different sites within the micrometeorology tower's flux footprint. The merged annual cycle of soil moisture from all sites is shown in Fig. 4b, and the annual soil temperature cycle is shown in Fig. 4c. The soil moisture cycle exhibits some interesting and classic features of western landscape hydrology, especially the tendency for persistent dryness and pulsed recharge of near-surface moisture, particularly in the warm season. Deeper into the soil, the moisture variability is significantly damped and there is evidence of persistent soil moisture there, regardless of extended summer dry periods. This deeper layer of persistent wet soil helps sustain some of the total evaporative flux from the ponderosa pine 


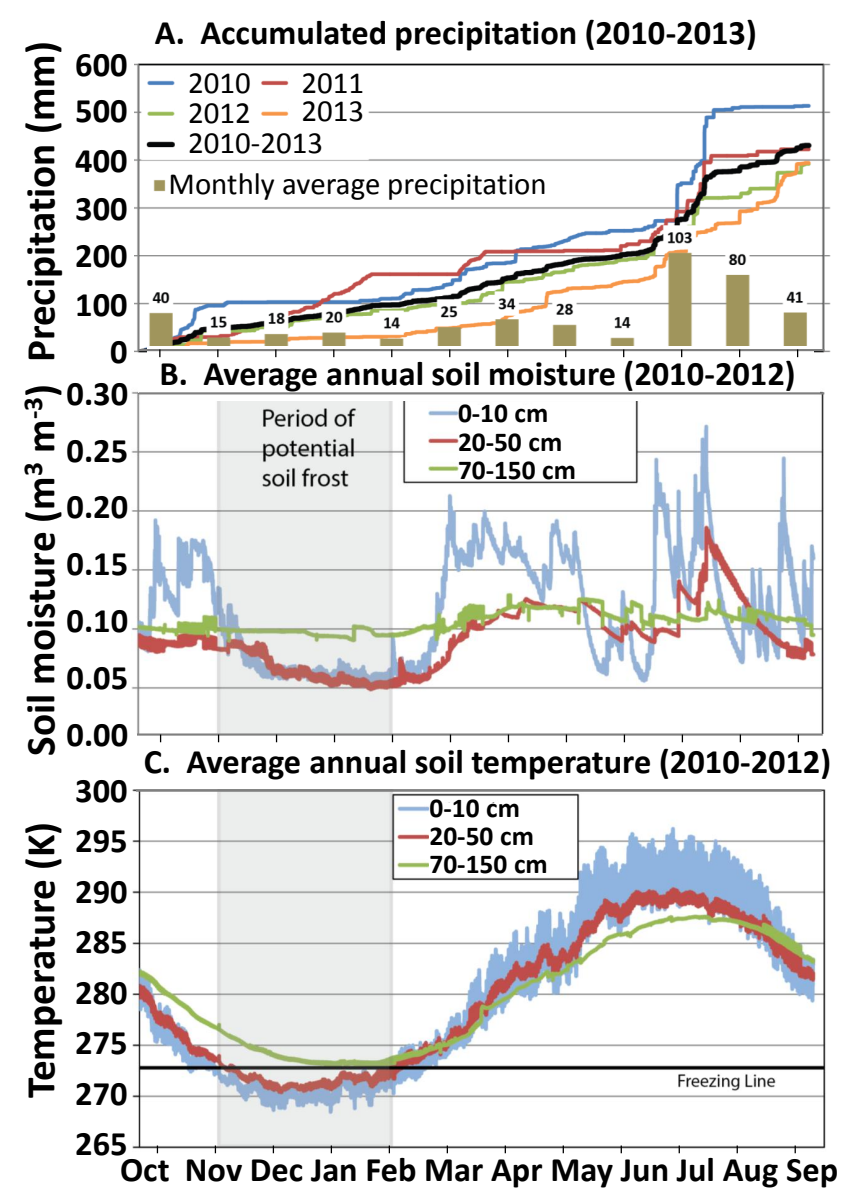

Figure 4. Hydrological measurement summary at the Manitou Experimental Forest Observatory. Annual accumulated precipitation from rain and snow (A), soil moisture at three depths (B) and soil temperature at three different depths (C). Panel (A) includes data from hydrological years 2010-2013, whereas (B) and (C) include data from 2010 to 2012.

ecosystem during the summer. There are extended periods of winter soil temperatures several degrees below $0{ }^{\circ} \mathrm{C}$, which extends to approximately $70 \mathrm{~cm}$ below the surface. These low soil temperatures indicate that significant amounts of soil water freeze (i.e., creates "soil frost") occasionally during the winter. The presence of soil frost is further evidenced by the sharp decline in recorded soil moisture values from December through late February. Suppressed soil moisture values corresponding to sub-zero soil temperatures are a classic measurement artifact due to the significant change in soil dielectric permittivity as water undergoes phase change from liquid to ice and back again at the freezing point. This meltwater release and periodic melting of the transient snowpack impart additional water pulses to the site. As previously mentioned, MEFO typically experiences an early-summer dry period before the onset of the monsoon rains, which is highly correlated with increased $\mathrm{CO}_{2}$ and BVOC fluxes. The semiarid climate creates very low midday stomatal conductance in ponderosa pine during the early- and late-summer dry periods (see Table 1), which protects the trees from water stress. When the monsoon rains start, these fluxes and stomatal conductance both increase substantially.

\subsection{Water manipulation effects on ponderosa pine}

Projected water limitations and higher temperatures are expected to put additional climate-induced physiological stresses on semi-arid forest ecosystems (Allen et al., 2010). To test hypotheses related to future climates, manipulation experiments must be carefully designed to ensure that data are representative of larger ecosystems responses (Beier et al., 2012). With these considerations in mind, another study at MEFO during 2010-2011 was designed to quantify the effect of different water treatments on the photosynthesis and respiration rates as well as BVOC emissions from mature trees (at least $10 \mathrm{~m}$ in height). Up to $50 \%$ of the incoming precipitation (snow and rain) was systematically diverted from the root zones $(10 \mathrm{~m} \times 10 \mathrm{~m}$ area $)$ around targeted trees using an array of troughs (see iii in Fig. 1c). The intercepted water was collected in barrels and then added to nearby trees, resulting in a water continuum delivered to the various trees from 0.5 to 1.5 times the total precipitation such that the total amount of water delivered to the entire plot remained constant. Physiological parameters (e.g., sapflow, photosynthesis and BVOC emissions) were measured on all trees within the experimental plot. Similar to the speciation seen in ambient air, branch-level measurements showed that the BVOCs emitted in the highest concentrations were methanol, 2-methyl-3-buten-2-ol and monoterpenes. Initial observations showed that seasonality in plant physiological processes and weather dynamics interact to produce complex controls over climate-dependent emissions of these compounds with a strong dependence on soil moisture and precipitation. If the climate in this region shifts to a drier summer regime, total BVOCs emitted from needles of this forest are likely to decrease, which will have implications for modeling both gas- and liquid-phase regional chemistry. Studies such as this exemplify the interdisciplinary research questions addressed by the BEACHON project, and are necessary to address the ecological system processes for inclusion in Earth system models as discussed in Sect. 1.1.

\section{Volatile organic compounds, oxidants and aerosol properties}

\subsection{Volatile organic compound observations}

Volatile organic compounds (VOCs) at MEFO are a mixture of biogenic and anthropogenic compounds. The summertime VOC signals are dominated by biogenic emissions, primarily methanol, ethanol, acetone, monoterpenes $\left(\mathrm{C}_{10} \mathrm{H}_{16}\right.$, abbreviated as MT) and 2-methyl-3-buten-2-ol $\left(\mathrm{C}_{5} \mathrm{H}_{10} \mathrm{O}\right.$, abbreviated as $232-\mathrm{MBO}$ or $\mathrm{MBO})$. Isoprene $\left(\mathrm{C}_{5} \mathrm{H}_{8}\right)$ is also 


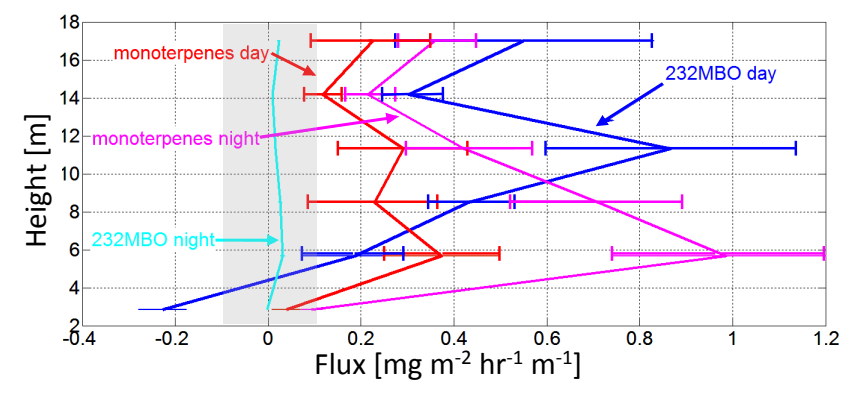

Figure 5. Average daytime and nighttime vertical fluxes of monoterpenes $\left(\mathrm{C}_{10} \mathrm{H}_{16}\right)$ and 2-methyl-3-buten-2-ol (232MBO, $\mathrm{C}_{5} \mathrm{H}_{10} \mathrm{O}$ ) during August 2010. The average daytime integrated flux ratio of $\mathrm{MBO}$ : monoterpenes is 1.65 . Fluxes within $\pm 0.1 \mathrm{mg} \mathrm{m}^{-2} \mathrm{~h}^{-1} \mathrm{~m}^{-1}$ are shown within the shaded gray area to indicate the detection limit. Error bars indicate the standard deviation of all measurements for that period and chemical species.

observed during summer, but to a much lesser extent $(\sim 10$ $20 \%$ of 232-MBO concentrations). Anthropogenic VOC concentrations are lower than the biogenic compounds and are typically transported into the area from the Colorado Springs or Denver metropolitan areas.

A variety of techniques have been used to measure VOCs from different levels on the chemistry tower, individual ponderosa pine branches and the ground. A quadrupole protontransfer-reaction mass spectrometer (PTR-MS; Ionicon Analytik, Innsbruck, Austria) measured a suite of selected VOCs (including methanol, acetonitrile, acetaldehyde, acetone + propanal, 232-MBO + isoprene, benzene, monoterpenes and sesquiterpenes) during portions of each of the 2008-2012 growing seasons. Under normal operating conditions, 232-MBO undergoes a dehydration reaction in the PTR-MS drift tube leading to a molecular ion of $\mathrm{m} / z=69$. This is the same ion as protonated isoprene, which is why they are reported as the sum of both species. Tower-based measurements alternated between a six-point gradient system $(1.6,5,8.5,12,17.7$ and $25.1 \mathrm{~m}$ above ground) and an eddy covariance (EC) flux system at the top level $(25.1 \mathrm{~m})$. In addition, a time-of-flight (TOF) PTR-MS (University of Innsbruck, Austria) was deployed for EC and concentration measurements above the ponderosa pine canopy in 2010 and 2011 (Kaser et al., 2013a, b). A selective reagent ion (SRI) PTR-TOF-MS (Ionicon Analytik, Innsbruck, Austria) instrument was used in 2011 to selectively distinguish 232-MBO from isoprene concentrations by using $\mathrm{NO}^{+}$as the reagent ion (Karl et al., 2012). This configuration was also used for 1 week in 2012 to continue these measurements for determining EC fluxes of 232-MBO and isoprene (Karl et al., 2014). Figure 5 shows the August 2010 vertical flux profiles for 232MBO and total MT calculated from gradient measurements using the methodology described in Karl et al. (2004). It is evident that MBO emissions follow a light-dependent pattern and that the fluxes increase with height up to $12 \mathrm{~m}$. MT emis- sion patterns were vertically more uniformly distributed suggesting that the understory (forest litter, bark and trunks) also contributed to the total emissions. Using site-specific leaf cuvette measurements as model inputs, MEGAN 2.1 estimates showed good agreement with the measured average daytime $232-\mathrm{MBO}+$ isoprene fluxes of $1.84 \mathrm{mg} \mathrm{m}^{-2} \mathrm{~h}^{-1}$. After the large rain and hail storm on 4 August 2010 (which produced $57.9 \mathrm{~mm}$ precipitation in an hour; see Sect. 2.1), monoterpene fluxes increased to $4.7 \mathrm{mg} \mathrm{m}^{-2} \mathrm{~h}^{-1}$, which is a factor $5-10$ higher than what is normally observed $\left(0.5-1 \mathrm{mg} \mathrm{m}^{-2} \mathrm{~h}^{-1}\right)$ (Kaser et al., 2013b). Figure 6a shows the sum of MT and $\mathrm{MBO}+$ isoprene concentrations and fluxes starting on this day (4 August) and ending 1 week later (11 August). The increases in both emissions and fluxes, which continue for $\sim 2$ days after the rain event, are evident. The missing flux data on the first day (and periodically throughout the measurement period) are due to turbulence characteristics that are not amenable to EC calculations as described in Sect. 1.3. The PTR-MS showed that ambient concentrations of several other BVOC (including cymene, camphor, nopinone, pinonaldehyde and sesquiterpenes) were also elevated after this vegetation disturbance.

The trace organic gas analyzer (TOGA; Apel et al., 2010) was deployed during the BEACHON-ROCS campaign to measure concentrations of isoprene, 232-MBO, speciated MT and over 25 other targeted compounds. Results showed that the MT speciation is dominated by $\alpha$-pinene, $\beta$-pinene and $\Delta$-3-carene (approximately $25 \%$ each). Other quantified monoterpenes include camphene (7\%), limonene (12\%), myrcene $(5 \%)$ and ocimene $(1 \%)$. Figure $6 \mathrm{~b}(1-4)$ shows August 2010 ambient diel concentrations of four selected VOCs reported by TOGA. The concentrations of the biogenic compounds MBO and MT are much higher than those of a typical anthropogenic compound (e.g., toluene) at this site, and the concentrations have different diurnal signatures. During the day, as the boundary layer grows and $\mathrm{OH}$ is present, MT concentrations are diminished even though their emissions are the greatest during this time. At night, the suppressed boundary layer height combined with decreased losses from $\mathrm{O}_{3}$ and $\mathrm{OH}$ reactions leads to elevated MT concentrations that generally increase from 18:00 to midnight and remain elevated until 06:00-07:00. MBO emissions from ponderosa pine are strongly light dependent (Harley et al., 1998; Kaser et al., 2013b), resulting in maximum emissions and ambient concentrations during midday with a secondary peak in the early morning associated with initiation of emissions before the morning breakup of the nocturnal boundary layer. The combination of all three instruments used during BEACHON-ROCS provided a unique opportunity to compare VOC measurement techniques under real-world conditions. The results were encouraging as the instruments agreed within $\sim 20 \%$ for monoterpenes and $\sim 10 \%$ for $232-\mathrm{MBO}$ + isoprene with $R^{2}$ values of $0.85-0.97$ (Kaser et al., 2013a).

Consistent with ambient concentration measurements, branch- and needle-level BVOC emission measurements 

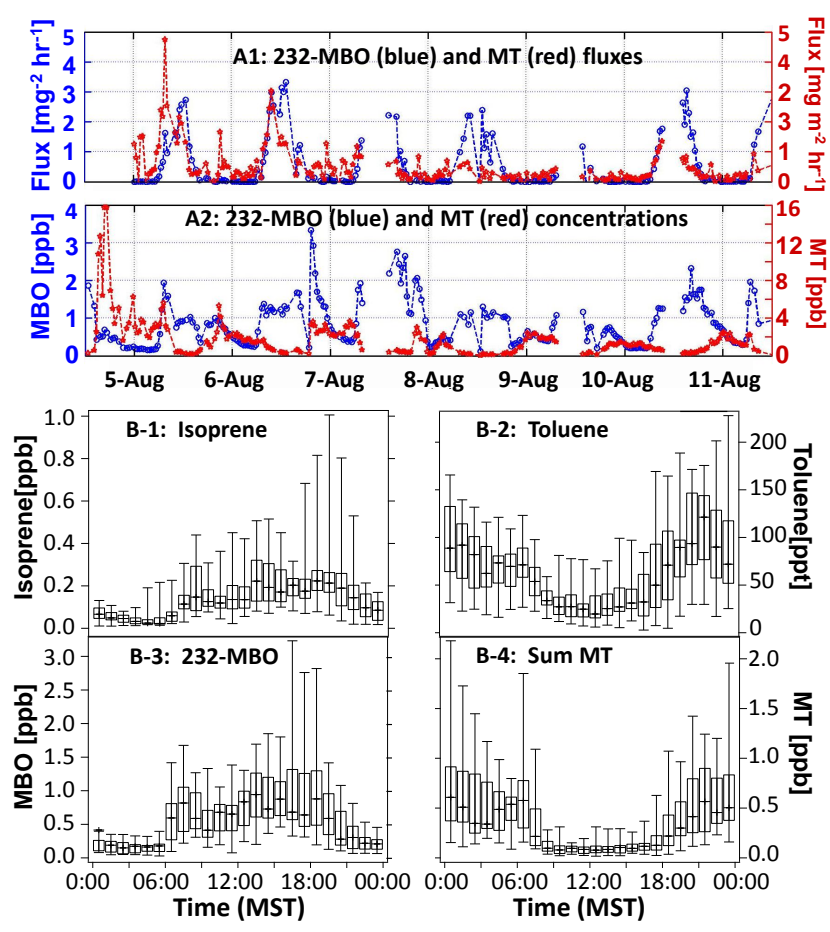

Figure 6. (A) (adapted from Kaser et al., 2013b) shows the sum of MT and MBO+isoprene measurements as reported by the PTRTOF-MS from $25.1 \mathrm{~m}$ on the chemistry tower from 4 August $(\mathrm{DOY}=216)$ to 11 August 2010 (DOY =223). A1 shows the above-canopy fluxes, while A2 shows the corresponding concentrations in ppbv. (B) shows diurnal profiles of (B-1) isoprene, (B-2) toluene, (B-3) MBO, and (B-4) sum of monoterpenes during all of August 2010 as measured using TOGA. Box boundaries indicate interquartile range, median is indicated as the line through the box, and whisker lengths indicate the total measurement range.

confirm the dominance of MBO in the emission profile; during daylight hours, MBO typically comprises $>85 \%$ of the emitted reactive BVOC mass. Similar to ambient observations, $\alpha$-pinene, $\beta$-pinene, $\Delta$-3-carene, camphene and limonene dominate the MT emissions, but a large number of other terpenoids are also emitted, including sabinene, myrcene, ocimene, $\alpha$-terpinene, $\beta$-phellandrene, cymene, terpinolene, $p$-cymenene and the oxygenated monoterpenes linalool, terpineol and methyl chavicol. In many cases, especially in high light conditions, linalool was a major component of the leaf-level emissions. A number of sesquiterpenes, dominated by $\beta$-farnesene, also appear in emission samples. For model inputs, BVOC speciation is an important consideration as different compounds (such as MT isomers with the same chemical formula) have different reaction rate constants with $\mathrm{OH}, \mathrm{O}_{3}$ and $\mathrm{NO}_{3}$, so their reaction products, pathways and atmospheric lifetimes can vary considerably. Additional soil BVOC flux measurements have been made using enclosures and a micrometeorological gradient technique at the site (Greenberg et al., 2012). These results suggested that emissions from the litter were negligible, contributing less than $1 \%$ of above-canopy emissions for all BVOCs measured.

A newly developed thermal desorption aerosol gas chromatograph-aerosol mass spectrometer (TAG-AMS) was deployed and used to analyze semi-volatile VOCs $\left(\sim \mathrm{C}_{14-}\right.$ $\mathrm{C}_{25}$ ) on a bihourly timescale. The sample collection, thermal desorption and chromatography systems have been described previously by Zhao et al. (2013); however the 2011 BEACHON-RoMBAS campaign was one of the first to couple it to the AMS as a detector (Williams et al., 2014). More than 70 semi-volatile gas-phase species were observed and quantified in the ambient atmosphere during the campaign. Source apportionment was used to identify the origin of these gas-phase species. Some were anthropogenic compounds (such as poly-aromatic hydrocarbons (PAH), oxygenated PAH and alkanes), but 23 species were identified to be terpenoid compounds of biogenic origin from a local source determined from positive matrix factorization (PMF).

In addition to direct VOC emissions and transported species, it is also important to consider oxidation products. These compounds can influence tropospheric ozone formation and oxidative capacity of the atmosphere and contribute to secondary organic aerosol. Concentrations and fluxes of two important oxygenated VOCs, formaldehyde ( $\mathrm{HCHO}$ ) and glyoxal (CHOCHO), were measured during the 2010 BEACHON-ROCS campaign (DiGangi et al., 2011, 2012) using fiber-laser-induced fluorescence (FILIF; Hottle et al., 2009) and laser-induced phosphorescence (Huisman et al., 2008). Ambient formaldehyde concentrations ranged between a minimum of $\sim 0.5 \mathrm{ppb}$ in the early morning hours (04:00 MST) and maximum values of $2-2.5 \mathrm{ppb}$ in the evening ( $\sim 20: 00 \mathrm{MST})$. Ambient glyoxal concentrations ranged between a minimum of $\sim 18 \mathrm{ppt}$ in the early morning hours (06:00 MST), and maximum values of 30-55 ppt in the evening $(\sim 17: 00 \mathrm{MST})$. The glyoxal: formaldehyde ratio maintained a stable diurnal cycle ratio with values of $\sim 1.5-2 \%$ in the early morning and at night, and rising to $\sim 2.5-3 \%$ in the middle of the days. In addition, to our knowledge, these canopy-scale HCHO eddy flux measurements are the first reported for any site. These results, coupled with enclosure measurements that showed minimal direct emissions, suggest a surprisingly large $\mathrm{HCHO}$ production source within the canopy air space. The midday $\mathrm{HCHO}$ fluxes were positive (upward) ranging from 37 to $131 \mu \mathrm{g} \mathrm{m}^{-2} \mathrm{~h}^{-1}$ (see Fig. 7b) and were correlated with temperature and radiation within the canopy. The missing $\mathrm{HCHO}$ source is thus consistent with oxidation of VOCs with lightand temperature-dependent emission profiles. The strength of HCHO fluxes cannot be accounted for by the oxidation of measured MBO and terpenes (also see Sect. 3.2). A detailed analysis regarding $\mathrm{HCHO}$ sources and oxidation is discussed in DiGangi et al. (2011). 


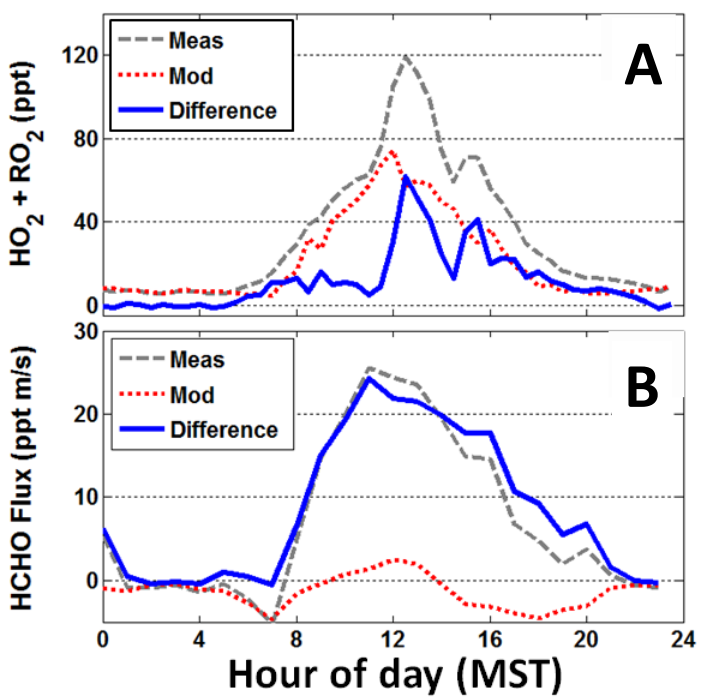

Figure 7. Average modeled and measured diurnal cycles of (A) within-canopy peroxy radical mixing ratios and (B) above-canopy formaldehyde fluxes. The measured and modeled results for both compounds include the hourly averages from the August 2010 BEACHON-ROCS intensive measurement campaign. Model calculations of HCHO fluxes and peroxy radicals are described in DiGangi et al. (2011) and Wolfe et al. (2014), respectively.

\subsection{Peroxy and hydroxyl radical observations}

Numerous studies (e.g., Stone et al., 2012) have highlighted discrepancies between modeled and measured radical concentrations in forested environments, suggesting a lack of understanding of the chemical processes driving secondary pollutant formation. While most research has focused on regions dominated by isoprene emissions, results from several investigations indicate gaps in our understanding of BVOC oxidation in MBO- and monoterpene-dominated areas similar to MEFO (Kurpius and Goldstein, 2003; Day et al., 2008; Farmer and Cohen, 2008; Wolfe et al., 2011; Mao et al., 2012). Both the 2010 BEACHON-ROCS and 2011 BEACHON-RoMBAS campaigns included measurements of the hydroxyl radical $(\mathrm{OH})$ and peroxy radicals $\left(\mathrm{HO}_{2}\right.$ and $\mathrm{RO}_{2}$; see Table $\mathrm{S} 1$ in the Supplement), using the techniques described by Edwards et al. (2003), Hornbrook et al. (2011) and Mauldin et al. (2001). This provided a unique opportunity to test our understanding of the chemical reactions that link BVOC oxidation with production of ozone and secondary organic aerosol (SOA) precursors.

Discrepancies between modeled and measured $\mathrm{HO}_{\mathrm{x}}$ (i.e., $\mathrm{OH}+\mathrm{HO}_{2}$ ) in regions with high BVOC levels have been primarily attributed to "missing" sources of $\mathrm{OH}$ (Thornton et al., 2002; Lelieveld et al., 2008; Hofzumahaus et al., 2009; Peeters et al., 2009). In the boundary layer, OH is produced both via "primary" sources, such as photolysis of ozone in the presence of water vapor, and via radical cycling reactions, such as reaction of $\mathrm{HO}_{2}$ with $\mathrm{NO}$.

$$
\begin{aligned}
& \mathrm{O}_{3}+h v \rightarrow \mathrm{O}\left({ }^{1} \mathrm{D}\right)+\mathrm{O}_{2} \\
& \mathrm{O}\left({ }^{1} \mathrm{D}\right)+\mathrm{H}_{2} \mathrm{O} \rightarrow 2 \mathrm{OH} \\
& \mathrm{HO}_{2}+\mathrm{NO} \rightarrow \mathrm{OH}+\mathrm{NO}_{2}
\end{aligned}
$$

In a detailed analysis of OH observations, Kim et al. (2013) demonstrate that radical recycling via Reaction (R3) is likely the dominant source of $\mathrm{OH}$ within the MEFO canopy. A 0-D box model underpredicts $\mathrm{HO}_{\mathrm{x}}$ concentrations relative to observations, implying unidentified sources of $\mathrm{HO}_{2}$. Using the same box model in a study focused on peroxy radical observations, Wolfe et al. (2014) confirm this result and identify several potential additional sources of both $\mathrm{HO}_{2}$ and $\mathrm{RO}_{2}$. Notably, it is suggested that oxidation of unmeasured, highly reactive BVOC could explain a significant portion of the missing peroxy radical source. Such a source could also explain the high $\mathrm{HCHO}$ fluxes observed during the same campaign (DiGangi et al., 2011; see Sect. 3.1). Figure 7a compares the hourly averaged measured and modeled total peroxy radical mixing ratios for BEACHON-ROCS (August 2010). As described in Wolfe et al. (2014), the difference between measured and modeled values corresponds to a total "missing" peroxy radical production rate of as much as $130 \mathrm{ppt} \mathrm{min}^{-1}$. For comparison, Fig. 7b shows measured and modeled HCHO fluxes (DiGangi et al., 2011). The additional $\mathrm{HCHO}$ production needed to reconcile modeled and measured formaldehyde fluxes is on the order of $65 \mathrm{ppt} \mathrm{min}-1$ at midday. Uncertainties in measurements and model results contribute to a significant overall uncertainty in these production rate estimates (approximately $\pm 50 \%$ ). Nonetheless, the similarity between these results - obtained via two essentially independent methods - supports the conclusion that VOC oxidation within the canopy is much stronger than predicted by canonical chemical mechanisms.

Analysis of the role of anthropogenic influence on the oxidation of BVOCs, especially via the influence of $\mathrm{NO}_{\mathrm{x}}$ on the fate of $\mathrm{RO}_{2}$, is of great current interest (Orlando and Tyndall, 2012), and MEFO is well suited for such studies (see also Sect. 4.1). Figure 8 a shows the measured $\mathrm{HO}_{2}, \mathrm{HO}_{2}+\mathrm{RO}_{2}$, $\mathrm{NO}$ and $\mathrm{NO}_{2}$ concentrations during a representative day in BEACHON-ROCS (24 August 2010), and Fig. 8c shows the corresponding wind speed and direction. On this day, upslope conditions (which can bring polluted urban air and are often seen at this site) were not observed, as the wind was generally out of the south or southwest, where there is relatively little anthropogenic influence. During the mid-morning as the boundary layer developed, an increase in $\mathrm{NO}_{\mathrm{x}}$ (Fig. 8a) can be seen, which was likely due to downward transport of a residual layer. The anthropogenic influence on the fate of $\mathrm{RO}_{2}$ is evident as the loss mechanism was initially dominated by the $\mathrm{RO}_{2}+\mathrm{NO}$ channel (Fig. 8b), but during midday as $\mathrm{NO}_{\mathrm{x}}$ concentrations decreased (due to the residual morning boundary layer breaking up and southwesterly flow to the site), the $\mathrm{RO}_{2}+\mathrm{HO}_{2}$ channel became the major loss 


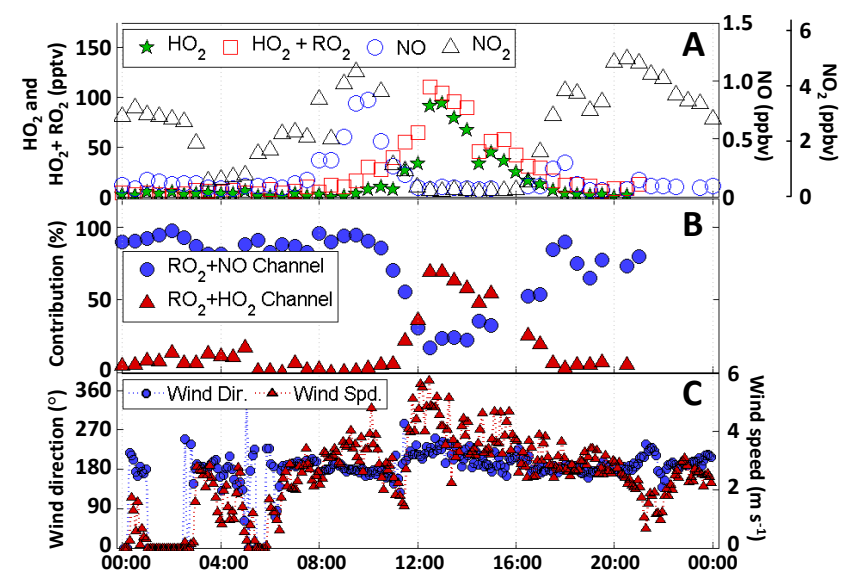

Figure 8. Examination of $\mathrm{RO}_{2}$ fate and its relation to anthropogenic influence on 24 August 2010 during BEACHON-ROCS. The first (A) shows median concentrations of $\mathrm{NO}, \mathrm{NO}_{2}, \mathrm{HO}_{2}$ and $\mathrm{HO}_{2}+\mathrm{RO}_{2}$ over the course of this day. Wind speed and direction (C) show the wind shifting from out of the south to out of the southeast just prior to noon (MST), indicating an anthropogenic influence from the Colorado Springs area. This transition is also reflected in the NO increase in panel A. The middle (B) shows the calculated $\mathrm{RO}_{2}$ loss percentage from reaction with $\mathrm{NO}$ or $\mathrm{HO}_{2}$ based on measured $\mathrm{NO}$ and $\mathrm{HO}_{2}$ concentrations and on rate constants obtained from the IUPAC database. Each symbol in (B) represents the median value from $30 \mathrm{~min}$ time bins. Figure adapted from DiGangi et al. (2012).

mechanism. While the patterns of these transitions do not appreciably affect the concentrations of biogenic and anthropogenic VOCs, the changes in the role of the different reaction channels are consistent with the measured $\mathrm{HCHO}$ and glyoxal concentrations (DiGangi et al., 2012) and measured and modeled $\mathrm{HO}_{2}+\mathrm{RO}_{2}$ concentrations indicated in Fig. 7. This competition between $\mathrm{NO}_{\mathrm{x}}$ and $\mathrm{HO}_{2}$ for reaction with the peroxy radicals $\left(\mathrm{RO}_{2}\right)$ affects the composition of multigenerational reaction products formed during gas-phase radical cycling and thus dictates, to a large extent, the production of ozone and organic aerosol precursors.

\subsection{Aerosol properties and composition}

Particle size distribution measurements (covering diameters from $4 \mathrm{~nm}$ to $2.5 \mu \mathrm{m}$ ) were conducted for nearly 2 years at MEFO starting in February 2010 and ending in January 2012. The instruments used for these measurements consist of the following components:

- optical particle counter (200-2500 nm), Lasair model 1002 from Particle Measurement Systems (Boulder, CO, USA);

- regular scanning mobility particle sizer (SMPS; 30$300 \mathrm{~nm}$ ): custom sheath air and HV control unit combined with TSI model 3081 differential mobility ana- lyzer (DMA) and TSI model 3760 condensation particle counter (CPC; TSI Inc., Shoreview, MN, USA); and

- nano-SMPS (4-30 nm): custom sheath air and HV control unit combined with TSI model 3085 DMA and TSI model 3025a CPC.

Particle size distributions started at midnight at exact $5 \mathrm{~min}$ intervals for a total of 288 size distributions per day. Frequent "small particle events" characterized by high concentrations of 4-20 nm particles were observed, especially during the summer season. The origin of these small particles is likely atmospheric nucleation (Kulmala et al., 2007), which is thought to be caused by reactions of gas-phase sulfuric acid with atmospheric bases such as ammonia and amines as well as oxidized organic compounds (Kirkby et al., 2011; Almeida et al., 2013). An example of three typical small particle events during July 2011 is shown in Fig. 9a, where the onset of each event is seen just prior to noon (MST). These events are common at MEFO in the summer, occurring 3-5 times per week during late morning or early afternoon, and typically coincide with changes in wind speed and direction. Figure $9 \mathrm{~b}$ shows wind speed and wind direction at the top of the chemistry tower and sulfate aerosol mass loadings measured by an aerosol mass spectrometer (described below). On each of these mornings the wind speed is fairly low $\left(\sim 1 \mathrm{~m} \mathrm{~s}^{-1}\right)$ at 08:00 MST with wind direction shifting from the south to a more northerly or northeasterly direction, indicating upslope transport from the Denver area. Thermal desorption chemical ionization mass spectrometer (TDCIMS) measurements during these nucleation events demonstrated that sub-20 nm particles were composed of 60\% sulfate by mass, whereas during non-event periods, sulfate contributed less than $40 \%$ of the mass to these small particles (Cui et al., 2014). In both event and non-event periods, the bulk aerosol mass is not significantly affected by this sulfate mass, as the majority of the total aerosol mass is dominated by larger particles. The correlation with wind direction and the increase in sulfate aerosol indicates that these events are anthropogenically induced. The scarcity of particles smaller than $10 \mathrm{~nm}$ on 29 July suggests that nucleation is occurring away from the site, either aloft (Mirme et al., 2010; Schobesberger et al., 2013) or in the mixed layer shortly ( $\sim 60 \mathrm{~min}$ or less) upwind of the site.

A fast mobility particle sizer (FMPS; Model 3091, TSI Inc., Shoreview, MN, USA) was used during BEACHONRoMBAS to measure size-dependent particle fluxes (Pryor et al., 2013). While the mean flux of both Aitken and nucleation mode particles was downwards, upward fluxes were frequently observed. Based on quadrant and timescale analyses using the University of Helsinki Multicomponent Aerosol (UHMA) model (Korhonen et al., 2004), Pryor et al. (2013) found that the upward fluxes of nucleation mode $(<30 \mathrm{~nm}$ diameter) particles were most strongly influenced by upward transport of particle-rich air from the canopy resulting from the growth of recently nucleated particles as well as 


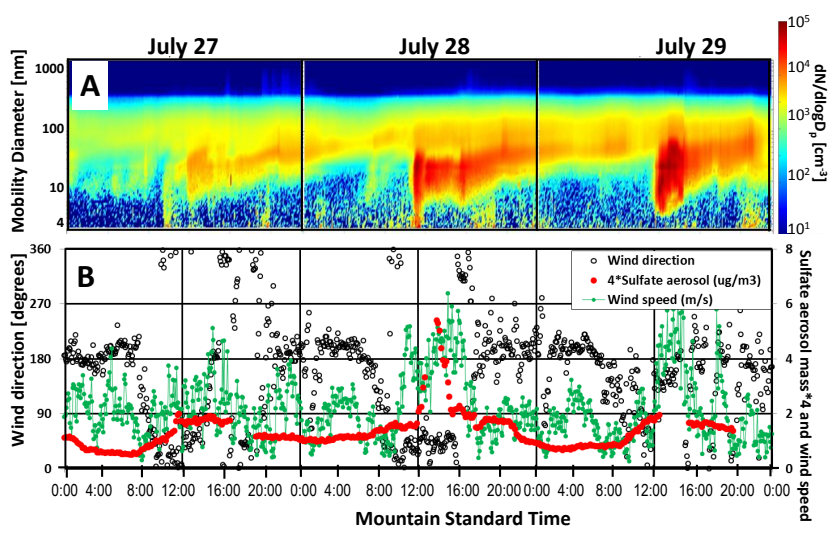

Figure 9. Three representative days of particle size distributions (A), wind speed, wind direction and sulfate aerosol mass (A) during 27-29 July 2011. In (A), the mobility diameter is on the $y$ axis, time is on the $x$ axis, and the color bar indicates particle number concentration $(\mathrm{d} N / \mathrm{d} \log D p)$ in $\mathrm{cm}^{-3}$. In $(\mathbf{B})$, the sulfate aerosol mass is multiplied by 4 and is listed on the second $y$ axis along with wind speed.

coagulation processes. Downward fluxes of the Aitken mode particles were more commonly linked to breakdown of the nocturnal inversion and entrainment of particle-depleted air from above the canopy.

Average particle number concentrations at this site are usually less than $2 \times 10^{3} \mathrm{~cm}^{-3}$, which is typical for rural continental environments, and concentrations rarely exceed $10^{4} \mathrm{~cm}^{-3}$. During the August 2011 BEACHONRoMBAS study, chemical speciation and mass loadings of non-refractory $\mathrm{PM}_{1}$ aerosol were measured using a highresolution time-of-flight aerosol mass spectrometer (HRToF-AMS; Aerodyne Research Inc., Billerica, MA; DeCarlo et al., 2006). Average mass loadings during the campaign were $2.5 \mu \mathrm{g} \mathrm{m}^{-3}$ (Fig. 10). Also included in this figure is black carbon aerosol as measured with a single-particle soot photometer (Droplet Measurement Technologies, Boulder, CO, model SP2). Approximately $75 \%$ of the total $\mathrm{PM}_{1}$ aerosol mass was comprised of organic aerosol (OA), with the rest composed primarily of ammonium sulfate. Nitrate concentrations were low and were shown to be primarily composed of organic nitrates (Fry et al., 2013). Black carbon (BC) aerosol mass was on the order of a few percent of the total submicron mass and more variable, often increasing and decreasing by an order of magnitude on hourly timescales. Transport from urban areas, fires and local traffic likely explain this variability. Figure 10b shows the size-resolved composition for the same species and time period. Ammonium and sulfate size distributions were centered at 300 $400 \mathrm{~nm}$, while organics and nitrate aerosol size distributions were centered at $\sim 250 \mathrm{~nm}$. The distinct size distributions of the chemical components indicate that these aerosols are not completely internally mixed. Figure 10c shows the monthlong daily distributions, which indicate a subtle diurnal cycle in organic aerosol, peaking at night, but with considerable day-to-day variability. The peak in average sulfate (and associated ammonium) at $\sim 16: 00-19: 00$ is primarily due to the influence of certain days when sulfate increased during late afternoon to early evening with corresponding $\mathrm{SO}_{2}$ increases (see spikes in Fig. 10a). The diurnal BC trends showed two peaks. The larger of these was in the evening ( 20:00) coincident with the regular prolonged impact of the urban plume in the afternoon and through the evening and was also seen in other anthropogenic species (e.g., $\mathrm{NO}_{\mathrm{x}}, \mathrm{CO}$ ). The smaller, shorter duration morning peak $(\sim 06: 00 \mathrm{MST})$ was also correlated with $\mathrm{NO}_{\mathrm{x}}$ and $\mathrm{CO}$. The reason for this morning BC increase could be due to the breakup of the shallow nocturnal boundary layer causing mixing down of more pollution-rich residual layer air, or an increase of local emission sources into a shallow morning boundary layer. It should be noted that the diameter measured from $\mathrm{BC}$ aerosol is the mass equivalent diameter $\left(D_{\mathrm{me}}\right)$ that was obtained by assuming a density of $1.8 \mathrm{~g} \mathrm{~cm}^{-3}$ as recommended by Moteki et al. (2010). The aerodynamic diameter is estimated to be at least 1.8 times larger than the $D_{\text {me }}$ shown in Fig. $10 \mathrm{~b}$ and could be larger than this if the $\mathrm{BC}$ were internally mixed with other non-BC compounds (e.g., organic coatings), or smaller if the particles had irregular shapes (DeCarlo et al., 2004).

$\mathrm{PM}_{2.5}$ collection on quartz fiber filters during the same campaign were analyzed for a variety of specific SOC (secondary organic carbon) and carbon isotopic measurements as described in Geron (2011) and Lewandowski et al. (2013). These results estimated that $0.5 \mu \mathrm{gC} \mathrm{m}{ }^{-3}$ could be attributed to specific SOC precursors. Hemiterpene precursor compounds (isoprene $+\mathrm{MBO}$ ) represented approximately half of the observed SOC, with monoterpenes contributing nearly the same amount to the total SOC. Isotopic measurements of these same filter samples found that the ${ }^{14} \mathrm{C}$ ratio was $0.71 \pm 0.11$ (range 0.52 to 0.88 ), indicating that roughly three-quarters of the particulate carbon observed during BEACHON-RoMBAS was of modern, nonpetrogenic origin. The fraction of modern carbon $(70 \%)$ at this site is less than values observed in eastern US forests. For example, Geron (2009) reported mean summertime values of $83 \%$ and with maximum values reaching $97 \%$ for those forests. Similarly, during summer months near forests in the eastern United States, Lewis et al. (2004) observed values between $\sim 80$ and $95 \%$. Organic tracer results (including oxidation products of isoprene, MT and 232-MBO) indicate that the lower fraction of contemporary carbon is primarily due to lower total biogenic emissions and lower organic mass loadings and not due to more traffic or other urban influences (Kleindienst et al., 2007). The modern carbon results from MEFO can also be compared to measurements at nine Interagency Monitoring for Protection of Visual Environments (IMPROVE) network sites. The values from the urban sites in this network averaged approximately $50 \%$ (Bench et al., 2007). 


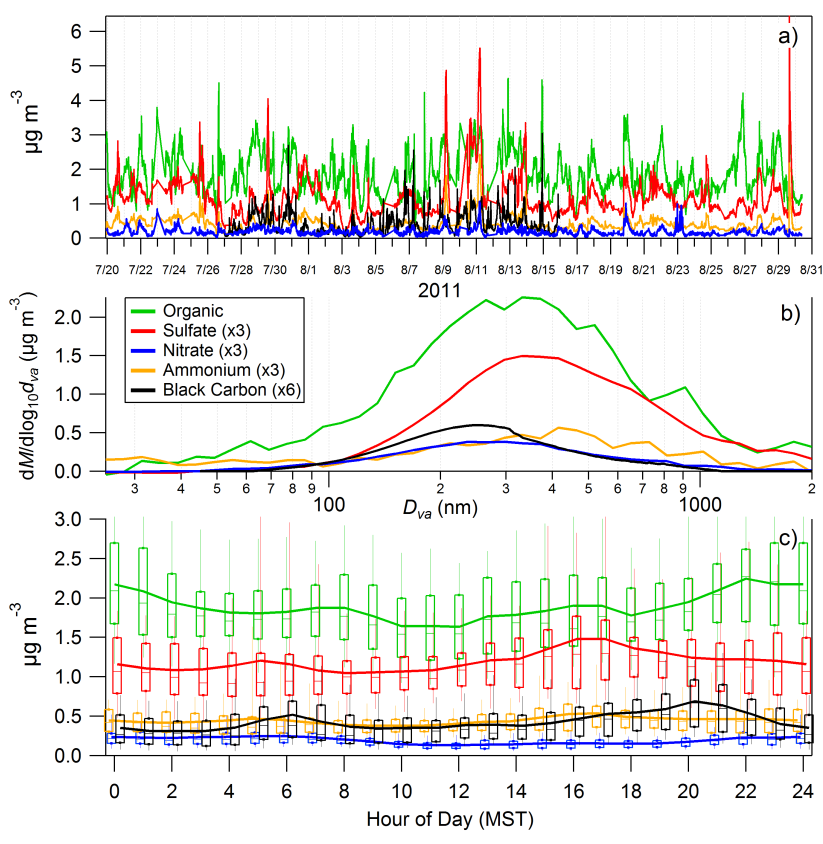

Figure 10. Aerosol mass spectrometer (AMS) and single-particle soot photometer (SP2) results of bulk $\mathrm{PM}_{1}$ aerosol composition during July and August 2011. Black carbon (BC) is measured by the SP2 and all others (organics, nitrate, sulfate and ammonium) are from the AMS. (a) shows the time series of mass loadings, (b) shows the average size-resolved aerosol distributions, and (c) shows the diurnal trends of each of the individual species averaged over the study period. The box plot boundaries in (c) represent the standard deviations, and the whisker lengths indicate the 25th and 75th percentiles of the measurements. The center line through each box indicates the median. Note that most of the aerosol is composed of organic species, and that in all panels, black carbon mass has been multiplied by 6 and the other (sulfate, nitrate, and ammonium) species' masses have been multiplied by 3 . The diameters for the $\mathrm{BC}$ measurements are estimated using an assumed density of $1.8 \mathrm{~g} \mathrm{~cm}^{-3}$ as indicated in the text (Sect. 3.3).

Gas- and aerosol-phase organic nitrate concentrations were quantified with thermal dissociation, laser-included fluorescence (TD-LIF; Day et al., 2002; Rollins et al., 2010) during summer 2011 (Fry et al., 2013). Gas-phase organic nitrate classes showed diurnal cycles peaking midday at $\sim 200$ ppt (total alkyl and multifunctional nitrates) $\sim 300 \mathrm{ppt}$ (total peroxy acyl nitrates) whereas total particle-phase organic nitrates peaked at night and early morning hours. Formation rates of gas-phase organic nitrates within the shallow nocturnal boundary layer were comparable to daytime rates of formation. It was observed that total gas- and particlephase organic nitrates had equilibrium-like responses to diurnal temperature changes, suggesting some reversible partitioning, although thermodynamic modeling could not explain all of the repartitioning. Additionally, the diurnal cycle of gas-particle partitioning supported modeled-predicted nighttime formation of lower volatility products, compared to daytime, from $\mathrm{NO}_{3}$ radical-initiated oxidation of monoterpenes. Aerosol-phase organic nitrates were also measured by AMS and showed good agreement with TD-LIF (Fry et al., 2013).

Hundreds of acids in the gas and aerosol phases were quantified in real-time during summer 2011 using a newly developed technique: the micro-orifice volatilization impactor high-resolution time-of-flight chemical ionization mass spectrometer (MOVI-HRToF-CIMS; Yatavelli et al., 2012, 2014). It allowed for direct measurement of the gasparticle partitioning of individual and bulk organic acids. Comparisons to absorptive partitioning modeling demonstrated that bulk organic acids seemed to follow absorptive partitioning, responding to temperature changes on timescales of $<1-2 \mathrm{~h}$, suggesting there were no major kinetic limitations to species evaporation. It was shown that species carbon number and oxygen content, together with ambient temperature, controlled the volatility of organic acids and are good predictors for partitioning. Moreover, the relationship between observed and model partitioning with carbon number and oxygen content pointed toward the likely importance of different classes of multifunctional organic acids that comprised the bulk of the acid groups (e.g., hydroxy acids, hydroperoxy acids, or polyacids but not keto acids).

A newly identified 232-MBO-derived organosulfate was identified in aerosol samples during BEACHON-RoMBAS, although at levels lower than reported for a previous Californian study (Zhang et al., 2012). The difference was tentatively attributed to the lower acidity of the pre-existing aerosol at BEACHON, as acidity is thought to greatly enhance the formation of this organosulfate. This species has the potential to be used as a tracer of SOA formation from 232-MBO.

Part of BEACHON-RoMBAS included the collection of time- and size-resolved biological aerosol properties. To our knowledge, this is the most extensive and comprehensive set of these measurements and data available. One key observation during the study was that rainfall events induced large increases in ambient fluorescent biological aerosol particle (FBAP) concentrations within the forest canopy (Huffman et al., 2013; Prenni et al., 2013), with concentrations remaining elevated for extended periods of time $(>12 \mathrm{~h})$ due to increased humidity and surface wetness. The largest observed increases, of more than an order of magnitude relative to dry conditions, occurred in the size range of $2-6 \mu \mathrm{m}$. Microscopic observations showed that these particles were dominated by biological cells at sizes with characteristics of bacterial aggregates and fungal spores (Huffman et al., 2013). Concentration increases that occurred during the rain events likely resulted from mechanical ejection of biological particles from surfaces (Constantinidou et al., 1990; Jones and Harrison, 2004), while a second, larger mode (which occurred after the rain) was likely actively emitted from biota on vegetated surfaces near the site (Elbert et al., 2007; Huffman et al., 2013). Contrary to the expectation that large 
particles will be washed out during precipitation, these data showed a significant increase in concentration and net upward flux of primary, supermicron particles after rain, which demonstrates a direct and important link of airborne particles to the hydrological cycle. Longer term measurements continued for 10 months (July 2011-June 2012), tracking the seasonal FBAP cycle at the site and observing trends with season, precipitation and other meteorological parameters (Schumacher et al., 2013).

\subsection{Cloud condensation nuclei and ice nuclei}

One of the primary goals of the BEACHON project was to determine the potential for biogenic emissions to serve as $\mathrm{CCN}$ and ice nuclei (IN), which can impact cloud properties and precipitation (e.g., Barth et al., 2005). It has been recently suggested that fungal spores may have large influences on SOA formation in the Amazonian forest (Pöhlker et al., 2012), and as discussed below, these biologically influenced particles can influence both CCN and IN. Changes in cloud properties and precipitation can, in turn, influence biogenic emissions, closing the loop on a potentially important feedback between the carbon and water cycles (Pöschl et al., 2010; Morris et al., 2014).

To better understand the influence of biogenic secondary organic aerosol on aerosol hygroscopicity and the seasonal variability of CCN, a continuous 14-month study (March 2010-May 2011) was performed at MEFO (Levin et al., 2012). This was followed by additional measurements during the summer 2011 BEACHON-RoMBAS intensive campaign, which allowed for direct comparison between aerosol hygroscopicity and aerosol chemical composition measurements (Levin et al., 2014). Aerosol hygroscopicity was described using the dimensionless hygroscopicity parameter, $\kappa$ (Petters and Kreidenweis, 2007), showing an annual averaged $\kappa$ value of $0.16 \pm 0.08$. This value is similar to $\kappa$ values measured in remote, forested regions, such as in Finland (Cerully et al., 2011) and the Brazilian Amazon (Gunthe et al., 2009), and is lower than the commonly assumed continental value of $\kappa=0.3$ (Andreae and Rosenfeld, 2008). Aerosol composition derived from the hygroscopicity measurements at MEFO indicated a predominance of organic species in the aerosol, leading to the low $\kappa$ measurement values. Direct comparison of organic mass fraction measured by aerosol mass spectrometry and filter measurements (discussed in Sect. 3.3) during BEACHON-RoMBAS agreed well with the composition derived from the hygroscopicity measurements. Organic mass fractions were found to be largest (up to $90 \%$ ) in the smallest particles (20$30 \mathrm{~nm}$ as measured by the TDCIMS). This fraction decreased with increasing particle diameter as measured by the AMS (Fig. 10b; Levin et al., 2014), and is consistent with the smallest particles being composed primarily of oxidized organic species from forest emissions. Results from the yearlong measurements showed that $\kappa$ was slightly higher dur- ing the winter months when biogenic emissions (which are strongly temperature dependent) are suppressed. The combination of these results suggests that secondary organic aerosol derived from biogenic emissions impact aerosol hygroscopicity and $\mathrm{CCN}$ number concentrations throughout the year.

In addition to the $\mathrm{CCN}$ measurements, IN have also been characterized. Ice-nucleating particles induce ice formation in clouds and are thought to be critical in initiating precipitation from mixed-phase clouds (DeMott et al., 2010). During BEACHON-RoMBAS, IN number concentrations were characterized at temperatures between -34 and $-9^{\circ} \mathrm{C}$. In addition, the particle sizes that induced freezing at temperatures greater than $-20^{\circ} \mathrm{C}$ were characterized via the droplet freezing technique. These particles as well as IN were both positively correlated with number concentrations of FBAP (Huffman et al., 2013; Prenni et al., 2013; Tobo et al., 2013). Similar to the precipitation-induced increases observed in biological particle concentrations, IN also increased during rain. The most dramatic example of this increase occurred on 2 August 2011, when a thunderstorm produced $19.6 \mathrm{~mm}$ of precipitation (maximum rainfall rate of $30 \mathrm{~mm} \mathrm{~h}^{-1}$ ). During this storm, IN concentrations at $-25^{\circ} \mathrm{C}$ increased from 2 to nearly $200 \mathrm{~L}^{-1}$ (Prenni et al., 2013). Correlation between IN and FBAP across the temperature range, coupled with DNA analysis of a portion of the residual IN, suggests that a significant fraction of the IN near the ground surface is composed of biological particles, particularly during and after rain events (Huffman et al., 2013; Prenni et al., 2013; Tobo et al., 2013). When lofted to altitudes where mixed-phase clouds persist, these biologically influenced IN can influence subsequent precipitation, providing yet another feedback between biogenic emissions and the hydrologic cycle, and further linking the biosphere, hydrosphere and atmosphere.

\section{Atmospheric processes at an urban-rural interface}

\subsection{Atmospheric chemistry}

As mentioned in Sect. 2.2, the MEFO site is primarily influenced by clean continental air, but is periodically impacted by polluted air advected from the Colorado Front Range urban areas. This makes the site a suitable location to investigate interactions between biogenic and anthropogenic emissions, and a variety of interesting questions can be addressed. For example, how are the oxidation pathways of locally emitted BVOC influenced by oxidant levels $\left(\mathrm{NO}_{3}, \mathrm{OH}\right.$ and $\left.\mathrm{O}_{3}\right)$ during clean and polluted conditions? In addition, to what extent does the transport of $\mathrm{SO}_{2}$, oxidants and VOCs from urban areas affect particle nucleation and growth? Model simulations can be initialized and parameterized using long-term and campaign-specific measurements of aerosols, VOCs, trace gases and meteorology. Results from these simulations can then be compared to observations. Local emissions are 
dominated by 232-MBO and monoterpenes, but these can be augmented by transport of anthropogenic species from the Front Range cities. Typical summertime ozone concentrations are 50-60 ppb during the afternoon, and decrease to $\sim 10-20 \mathrm{ppb}$ at night. Nitrogen oxides $\left(\mathrm{NO}_{\mathrm{x}}\right)$ are generally dominated by $\mathrm{NO}_{2}$, with typical values $\sim 0.5$ to $4.0 \mathrm{ppb}$, although occasional urban influences can cause the concentration to increase to $8-10 \mathrm{ppb}$. NO concentrations are much lower - typically less than $0.5 \mathrm{ppb}$, and rarely exceed $1.0 \mathrm{ppb}$. Since the area is relatively rural with low $\mathrm{NO}_{\mathrm{x}}$ concentrations, ozone is not titrated away at night as would typically happen in an urban environment. Average $\mathrm{SO}_{2}$ concentrations are quite low year-round, averaging less than $0.2 \mathrm{ppb}$, but concentrations can occasionally spike to $\sim 2.0 \mathrm{ppb}$. The average August $2011 \mathrm{CO}$ concentration was $123 \mathrm{ppb}$ (standard deviation of $27 \mathrm{ppb}$ ). These values increase when urban air is transported to the site, but rarely exceed $150 \mathrm{ppb}$. Periodic $\mathrm{CO}$ measurements at other times of year have shown similar consistent results. These direct measurements provide valuable insight into the range of atmospheric conditions that the site experiences, and can be used as initial inputs and provide constraints in modeling efforts. The relatively clean conditions combined with periodic, well-defined urban perturbations make it an ideally situated location for studying atmospheric processes at the rural-urban interface. An example of this was demonstrated in Fig. 8 (adapted from DiGangi et al., 2012), which shows the ambient concentrations of $\mathrm{HO}_{2}, \mathrm{RO}_{2}, \mathrm{NO}$ and $\mathrm{NO}_{2}$ in panel a and the corresponding wind speed and direction in panel $\mathrm{c}$ during a representative BEACHON-ROCS day (24 August 2010). In the early morning, both $\mathrm{HO}_{2}$ and $\mathrm{RO}_{2}$ are very low $(<20 \mathrm{ppt})$, accompanied by low wind speeds. During the day, the wind speed increases and becomes southeasterly with an accompanying increase in NO (likely from the Colorado Springs area, $\sim 40 \mathrm{~km} \mathrm{SE}$ of the site). At $\sim 10: 30$, there is an abrupt change in wind direction with air coming from the SW (where there is little anthropogenic influence), accompanied by a sharp decrease in $\mathrm{NO}$ concentrations. Concentrations of $\mathrm{HO}_{2}+\mathrm{RO}_{2}$ then reach maximum values during the early afternoon, at which point the $\mathrm{HO}_{2}$ concentrations become maximized and the loss mechanism for $\mathrm{RO}_{2}$ is through the $\mathrm{RO}_{2}+\mathrm{HO}_{2}$ channel (Fig. 8b). These observations demonstrate that the fate of $\mathrm{RO}_{2}$ radicals at the site is dominated by reaction with $\mathrm{HO}_{2}$ under clean-air conditions and by reaction with $\mathrm{NO}$ when influenced by urban air. The transitions between the two regimes can be quite sharp, making the site well suited for studying these types of transitions.

\subsection{Coupled weather and chemistry modeling}

Three-dimensional coupled meteorology and chemistry simulations of MEFO and the surrounding region have been conducted using the Weather Research and Forecasting model with chemistry (WRF-Chem; Grell et al., 2005; Fast et al., 2006). These model runs include gas-phase and aerosol
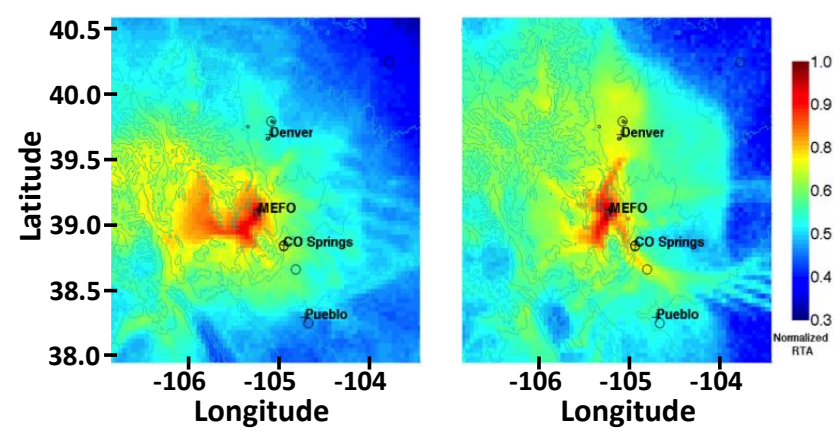

Figure 11. Residence time analysis (RTA) from WRF-Chem estimates the amount of time that air masses originate from the various locations in the region. These simulations estimate $48 \mathrm{~h}$ backtrajectories at MEFO (27 July to 26 August 2011). Three major Front Range cities (Denver, Colorado Springs and Pueblo) are shown, and open circles indicate the cities' primary coal-fired power plants. The left panel indicates that the majority of the low $\mathrm{NO}_{2}$ concentration results $(0-50$ th percentile) are from air masses that originate from the west. The right panel shows that the highest $10 \%$ of $\mathrm{NO}_{2}$ concentrations originate from the Front Range cities and are advected to the site.

chemistry as well as aerosol effects on radiation and clouds. Simulations were performed at $4 \mathrm{~km}$ horizontal grid spacing and compared to ground measurements during the intensive BEACHON-ROCS and BEACHON-RoMBAS measurement periods. These modeling studies focused particularly on organic aerosol (OA) formation from forest BVOC emissions, and the influence of anthropogenic pollutants transported to the site. To study OA formation, the WRF-Chem model was configured as described in Fry et al. (2013) using the SOA module based on Hodzic and Jimenez (2011) for anthropogenic precursors and Shrivastava et al. (2011) for biogenic precursors. To study the influence of anthropogenic pollution on aerosol formation, the WRF-Chem model was configured as described in Cui et al. (2014). Back-trajectory calculations based on WRF-Chem simulations confirm that these pollutants are advected from the Front Range urban area (Fig. 11). Elevated concentrations of $\mathrm{NO}_{2}$ (and $\mathrm{SO}_{2}$, not shown) measured onsite coincide with the arrival of polluted air masses from Denver or Colorado Springs, whereas low concentrations are associated with cleaner air advected from the west. The effect of anthropogenic pollution on predicted OA composition suggests a fraction of modern carbon that is on the order of that measured. Figure 12 shows that $30 \%$ or more of $\mathrm{OA}$ is influenced by anthropogenic species through either the formation of secondary organic aerosols by nighttime $\mathrm{NO}_{3}$ chemistry, increased $\mathrm{OH}$ and $\mathrm{O}_{3}$ oxidation, or the direct transport of anthropogenic OA to the site. $\mathrm{NO}_{3}$ chemistry contributes to larger SOA concentrations at night when the boundary layer is shallow (Fry et al., 2013), but the overall contribution to the actual aerosol column relevant to radiative forcing is small (a $1 \mu \mathrm{g} \mathrm{m}^{-3}$ mass concentration represents a $100 \mu \mathrm{g} \mathrm{m}^{-2}$ column density in a $100 \mathrm{~m}$ nighttime 
Modeled and measured total organic aerosol (TOA): July 16-August 25, 2011

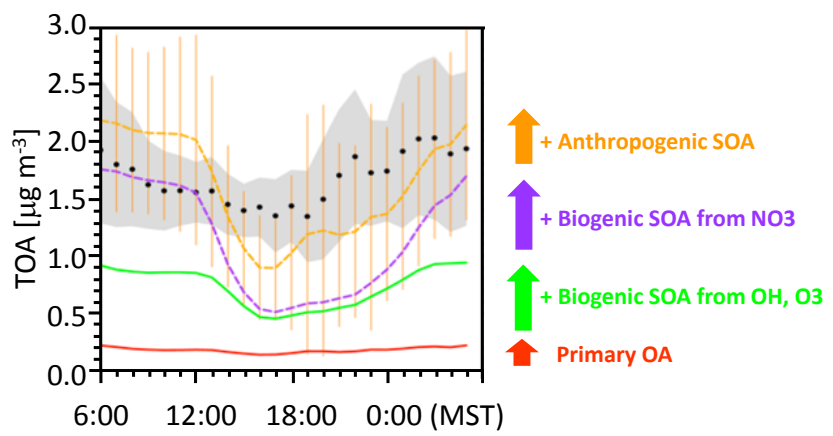

Figure 12. Modeled and measured average diurnal profiles of total organic aerosol (TOA) mass concentrations at MEFO during BEACHON-RoMBAS 2011. Aerosol mass spectrometry (AMS) observations are shown as black circles (with $1 \sigma$ variability shown in gray). Predicted TOA is indicated in yellow (with variability shown by the yellow bars). The predicted TOA is the sum of the contributions: primary OA (red), biogenic secondary organic aerosol (SOA) from $\mathrm{OH}$ and $\mathrm{O}_{3}$ chemistry (green), biogenic SOA from $\mathrm{NO}_{3}$ nighttime chemistry (purple) and anthropogenic SOA (yellow). Each plot (starting with green) is additive (equal to that process plus the sum of the processes below it): for example, the purple plot shows the contributions from primary OA, biogenic SOA from $\mathrm{OH}$ and $\mathrm{O}_{3}$ and biogenic $\mathrm{SOA}+\mathrm{NO}_{3}$. Biogenic SOA (both day and night) are the largest contributors to TOA, but anthropogenic species (yellow) also make a significant contribution.

boundary layer). Daytime aerosol mass loadings contribute much more to the regional aerosol mass due to the combination of the higher mass loadings and fully developed boundary layer $\left(2 \mu \mathrm{g} \mathrm{m}{ }^{-3}\right.$ corresponds to $4000 \mu \mathrm{g} \mathrm{m}^{-2}$ in a $2 \mathrm{~km}$ daytime boundary layer, a 40-fold increase column height).

Small particle events (see Sect. 3.3) were correlated with elevated $\mathrm{SO}_{2}$ concentrations. Figure 13 shows the onset and subsequent growth of particles at the site during one of these events (29 July 2011) as observed (panel a) and the corresponding WRF-Chem simulation (panel b). Model results indicate that initial particle formation is triggered by anthropogenic $\mathrm{SO}_{2}$, whereas subsequent particle growth is driven by condensation of BVOC oxidation products (Cui et al., 2014) as discussed in Sect. 3.3. Growth rates were calculated using the number mean diameter defined by (Matsui et al., 2011)

$\mathrm{NMD}=\frac{\sum_{i} D p_{i} \times N_{i}}{\sum_{i} N_{i}}$,

where $D p_{i}$ and $N_{i}$ are the diameter (nm) and number concentration, respectively. The model simulations estimated that the average particle growth rates during these events (from 4 to $40 \mathrm{~nm}$ mobility diameter) were $3.4 \mathrm{~nm} \mathrm{~h}^{-1}$. The observed values calculated from SMPS measurements (average $=2.0 \mathrm{~nm} \mathrm{~h}^{-1}$ ) are less than the simulated values, but in reasonable agreement with other reports from forested re-
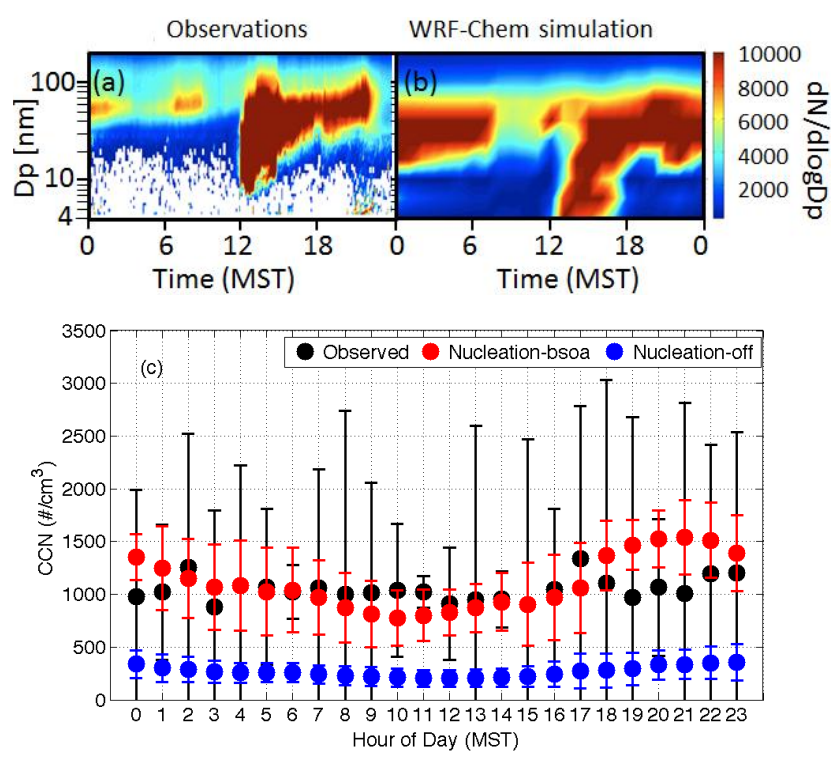

Figure 13. 29 July 2011 particle size distributions observed (a) and modeled with WRF-Chem (b). White areas in (a) indicate that no counts were observed for that diameter particle at that time. (c) shows the observed (black) and predicted (red) CCN concentrations averaged over the 10-15 August 2011 time period. The blue circles are the simulations when nucleation is not included, which demonstrates the importance of particle nucleation for $\mathrm{CCN}$ formation.

gions in Indiana, USA $\left(2.5 \mathrm{~nm} \mathrm{~h}^{-1}\right.$; Pryor et al., 2010), and Finland (2.9 $\mathrm{nm} \mathrm{h}^{-1}$; Jaatinen et al., 2009). It should also be noted that there is considerable variability in reported growth rates, and this value is highly dependent upon the chosen diameter range.

The impact of biogenic aerosols on clouds and precipitation was also investigated as part of the BEACHON project. Figure 13c shows the effect of new particle formation on cloud condensation nuclei $(\mathrm{CCN})$ concentrations at the site during 5 days in August 2011. The observed CCN concentrations are compared with the predicted values, computed with and without accounting for new particle formation in the model. These results show that modeled $\mathrm{CCN}$ concentration predictions (at $0.5 \%$ supersaturation) significantly underpredict the actual measured concentrations unless nucleation is taken into account. This demonstrates the importance of aerosol nucleation to accurately parameterize aerosol-cloud interactions. In future climate scenarios, it has been hypothesized that warmer temperatures (and potentially higher biogenic emissions) could have a negative climate feedback (Paasonen et al., 2013). This is because more oxidation products from $\mathrm{BVOC}$ emissions will be available for condensation, resulting in higher $\mathrm{CCN}$ concentrations and consequently increased cloud cover. Other regional modeling efforts utilizing BEACHON-ROCS and RoMBAS data are still underway to explore a variety of bio-hydro-atmosphere relationships. 


\section{Key findings from 2008-2011 field campaigns}

The Manitou Experimental Forest Observatory has hosted three multi-investigator intensive measurement campaigns, each designed to focus on specific aspects of bio-hydroatmosphere interactions. Measurements made during the BEACHON-SRM08 (Southern Rocky Mountains 2008) study provided an initial characterization of the site, provided data (specifically aerosol number and mass concentrations, CCN and hygroscopicity) for evaluation of regionalscale model simulations examining aerosol-cloud interactions, and enabled the identification of key scientific questions that could be addressed during subsequent field campaigns. The 2010 BEACHON-ROCS (Rocky Mountain Organic Carbon) study focused on BVOC oxidation and associated implications for oxidant cycling and distributions. The results showed that while there are compounds in the ambient air not typically measured by standard techniques, there is evidence that missing $\mathrm{OH}$ sinks are associated with oxidation products of known BVOC rather than primary emissions of unknown BVOC. The study also demonstrated that considerable BVOC oxidation takes place within the canopy air space. The following year (2011) the BEACHONRoMBAS (Rocky Mountain Biogenic Aerosol Study) took place to characterize a multitude of aerosol processes at the site and incorporate the findings from the gas-phase measurements of BEACHON-ROCS into modeling efforts. Among the many measurements performed were IN, CCN, particle size distributions, chemical speciation of bulk aerosol and small $(<30 \mathrm{~nm})$ particles, gas- and particle-phase partitioning, black carbon, elemental: organic carbon (EC:OC) ratios, gas-phase nitrate and $\mathrm{NO}_{\mathrm{x}}$, and supermicron biological particles. This campaign also included many of the same gas-phase measurements from 2010 to further characterize BVOC emissions, oxidant levels and oxidation products. Many of the long-term seasonal observations (see Table S1 in the Supplement) have been valuable in characterizing the site, and for interpreting measurements taken during the intensive measurement campaigns. Table S2 in the Supplement lists the publication results from the past 5 years based on MEFO observations. Future investigations and data analysis from past measurements are expected to result in further publications, additional observations and more collaborative research. This is not intended to be an exhaustive list but rather provide context for the research site and further information for past, present and future researchers.

\section{Conclusions}

Observations at the Manitou Experimental Forest Observatory have provided important data for understanding terrestrial-atmosphere interactions in a semi-arid ponderosa pine forest that is typical of the Colorado Front Range urbanrural interface. Studies of biogenic emissions and their influ- ence on gas-phase chemistry, aerosol properties and cloud condensation nuclei have led to a number of interesting conclusions - some of which have been summarized herein. High-frequency turbulence measurements coupled with corresponding $\mathrm{CO}_{2}$, water and energy fluxes at the site are now being incorporated into the land-surface schemes of climate models to more accurately represent canopy influences. The unique observational data are available for other model parameterization and evaluation studies. The infrastructure exists to enable additional measurements and future scientific measurement campaigns as well as for testing new instruments, measurement intercomparisons, graduate and undergraduate student development and other studies involving terrestrial-atmospheric exchange processes. MEFO is a collaborative facility that is maintained through a cooperative agreement between NCAR and the USDA Forest Service and is available to the scientific community for training, model development and evaluation, and scientific discovery.

\section{The Supplement related to this article is available online at doi:10.5194/acp-14-6345-2014-supplement.}

Acknowledgements. The authors would like to acknowledge generous field support from Richard Oakes (USDA Forest Service, Manitou Experimental Forest Site Manager). Authors from Colorado State University were supported through NSF grant ATM-0919042. Authors from the University of Colorado were supported by NSF grant ATM-0919189 and United States Department of Energy grant DE-SC0006035. Authors from the National Center for Atmospheric Research were supported by NSF grant ATM-0919317 and US Department of Energy grant DE-SC00006861. T. Karl was also supported by the EC Seventh Framework Programme (Marie Curie Reintegration program, "ALP-AIR", grant no. 334084). S. C. Pryor (Indiana University) was supported by NSF ATM-1102309. Authors from the University of Innsbruck were supported by the Austrian Science Fund (FWF) under project number L518-N20. L. Kaser was also supported by a DOC-fFORTE fellowship of the Austrian Academy of Science. Authors from the University of Wisconsin-Madison were supported by NSF grant ATM-0852406, the BEACHON project and NASA-SBIR Phase I \& II funding. Contributions from Los Alamos National Laboratory (LANL) were funded by the United States Department of Energy's Atmospheric System Research (project F265, KP1701, M. K. Dubey as principal investigator). A. C. Aiken also thanks LANL - Laboratory Directed Research and Development for a director's postdoctoral fellowship award. The authors would also like to acknowledge substantial participation and input from the Max Planck Institute for Chemistry (MPIC; Mainz, Germany), which was funded by the Max Planck Society (MPG) and the Geocycles Cluster Mainz (LEC Rheinland-Pfalz). J. A. Huffman acknowledges internal faculty support from the University of Denver. The United States Environmental Protection Agency (EPA), through its Office of Research and Development, collaborated in the research described here. The manuscript has been subjected to peer review and has been cleared for publication by the EPA. Mention of trade names or commercial products 
does not constitute endorsement or recommendation for use. The National Center for Atmospheric Research is sponsored by the National Science Foundation. Any opinions, findings and conclusions or recommendations expressed in the publication are those of the authors and do not necessarily reflect the views of the National Science Foundation or the US Environmental Protection Agency.

Edited by: R. Holzinger

\section{References}

Allen, C. D., Macalady, A. K., Chenchouni, H., Bachelet, D., McDowell, N., Vennetier, M., Kitzberger, T., Rigling, A., Breshears, D. D., Hogg, E. H., Gonzalez, P., Fensham, R., Zhang, Z., Castro, J., Demidova, N., Lim, J. H., Allard, G., Running, S. W., Semerci, A., and Cobb, N.: A global overview of drought and heat-induced tree mortality reveals emerging climate change risks for forests, Forest Ecol. Manag., 259, 660684, doi:10.1016/j.foreco.2009.09.001, 2010.

Almeida, J., Schobesberger, S., Kurten, A., Ortega, I. K., Kupiainen-Maatta, O., Praplan, A. P., Adamov, A., Amorim, A., Bianchi, F., Breitenlechner, M., David, A., Dommen, J., Donahue, N. M., Downard, A., Dunne, E., Duplissy, J., Ehrhart, S., Flagan, R. C., Franchin, A., Guida, R., Hakala, J., Hansel, A., Heinritzi, M., Henschel, H., Jokinen, T., Junninen, H., Kajos, M., Kangasluoma, J., Keskinen, H., Kupc, A., Kurten, T., Kvashin, A. N., Laaksonen, A., Lehtipalo, K., Leiminger, M., Leppa, J., Loukonen, V., Makhmutov, V., Mathot, S., McGrath, M. J., Nieminen, T., Olenius, T., Onnela, A., Petaja, T., Riccobono, F., Riipinen, I., Rissanen, M., Rondo, L., Ruuskanen, T., Santos, F. D., Sarnela, N., Schallhart, S., Schnitzhofer, R., Seinfeld, J. H., Simon, M., Sipila, M., Stozhkov, Y., Stratmann, F., Tome, A., Trostl, J., Tsagkogeorgas, G., Vaattovaara, P., Viisanen, Y., Virtanen, A., Vrtala, A., Wagner, P. E., Weingartner, E., Wex, H., Williamson, C., Wimmer, D., Ye, P. L., Yli-Juuti, T., Carslaw, K. S., Kulmala, M., Curtius, J., Baltensperger, U., Worsnop, D. R., Vehkamaki, H., and Kirkby, J.: Molecular understanding of sulphuric acid-amine particle nucleation in the atmosphere, Nature, 502, 359-363, doi:10.1038/nature12663, 2013.

Alo, C. A. and Wang, G. L.: Hydrological impact of the potential future vegetation response to climate changes projected by 8 GCMs, J. Geophys. Res.-Biogeo., 113, G03011, doi:10.1029/2007jg000598, 2008.

Andreae, M. O. and Rosenfeld, D.: Aerosol-cloudprecipitation interactions. Part 1 . The nature and sources of cloud-active aerosols, Earth Sci. Rev., 89, 13-41, doi:10.1016/j.earscirev.2008.03.001, 2008.

Apel, E. C., Emmons, L. K., Karl, T., Flocke, F., Hills, A. J., Madronich, S., Lee-Taylor, J., Fried, A., Weibring, P., Walega, J., Richter, D., Tie, X., Mauldin, L., Campos, T., Weinheimer, A., Knapp, D., Sive, B., Kleinman, L., Springston, S., Zaveri, R., Ortega, J., Voss, P., Blake, D., Baker, A., Warneke, C., Welsh-Bon, D., de Gouw, J., Zheng, J., Zhang, R., Rudolph, J., Junkermann, W., and Riemer, D. D.: Chemical evolution of volatile organic compounds in the outflow of the Mexico City Metropolitan area, Atmos. Chem. Phys., 10, 2353-2375, doi:10.5194/acp-10-23532010, 2010.
Barth, M., McFadden, J. P., Sun, J. L., Wiedinmyer, C., Chuang, P., Collins, D., Griffin, R., Hannigan, M., Karl, T., Kim, S. W., Lasher-Trapp, S., Levis, S., Litvak, M., Mahowald, N., Moore, K., Nandi, S., Nemitz, E., Nenes, A., Potosnak, M., Raymond, T. M., Smith, J., Still, C., and Stroud, C.: Coupling between land ecosystems and the atmospheric hydrologic cycle through biogenic aerosol pathways, B. Am. Meterol. Soc., 86, 1738-1742, doi:10.1175/bams-86-12-1738, 2005.

Battaglia, M. A., Rocca, M. E., Rhoades, C. C., and Ryan, M. G.: Surface fuel loadings within mulching treatments in Colorado coniferous forests, Forest Ecol. Manag., 260, 1557-1566, doi:10.1016/j.foreco.2010.08.004, 2010.

Beier, C., Beierkuhnlein, C., Wohlgemuth, T., Penuelas, J., Emmett, B., Korner, C., de Boeck, H. J., Christensen, J. H., Leuzinger, S., Janssens, I. A., and Hansen, K.: Precipitation manipulation experiments - challenges and recommendations for the future, Ecol. Lett., 15, 899-911, doi:10.1111/j.14610248.2012.01793.x, 2012.

Bench, G., Fallon, S., Schichtel, B., Malm, W., and McDade, C.: Relative contributions of fossil and contemporary carbon sources to $\mathrm{PM}_{2.5}$ aerosols at nine Interagency Monitoring for Protection of Visual Environments (IMPROVE) network sites, J. Geophys. Res.-Atmos., 112, D10205, doi:10.1029/2006jd007708, 2007.

Burgess, S. S. O., Adams, M. A., Turner, N. C., Beverly, C. R., Ong, C. K., Khan, A. A. H., and Bleby, T. M.: An improved heat pulse method to measure low and reverse rates of sap flow in woody plants, Tree Physiol., 21, 589-598, 2001.

Carslaw, K. S., Boucher, O., Spracklen, D. V., Mann, G. W., Rae, J. G. L., Woodward, S., and Kulmala, M.: A review of natural aerosol interactions and feedbacks within the Earth system, Atmos. Chem. Phys., 10, 1701-1737, doi:10.5194/acp-10-17012010, 2010.

Cerully, K. M., Raatikainen, T., Lance, S., Tkacik, D., Tiitta, P., Petäjä, T., Ehn, M., Kulmala, M., Worsnop, D. R., Laaksonen, A., Smith, J. N., and Nenes, A.: Aerosol hygroscopicity and CCN activation kinetics in a boreal forest environment during the 2007 EUCAARI campaign, Atmos. Chem. Phys., 11, 12369-12386, doi:10.5194/acp-11-12369-2011, 2011.

Constantinidou, H. A., Hirano, S. S., Baker, L. S., and Upper, C. D.: Atmospheric dispersal of ice nucleation-active bacteria: The role of rain, Phytopathology, 80, 934-937, 1990.

Cui, Y. Y., Hodzic, A., Smith, J. N., Ortega, J., Brioude, J., Matsui, H., Turnipseed, A., Winkler, P., and de Foy, B.: Modeling ultrafine particle growth at a pine forest site influenced by anthropogenic pollution during BEACHON-RoMBAS 2011, Atmos. Chem. Phys. Discuss., 14, 5611-5651, doi:10.5194/acpd14-5611-2014, 2014.

Day, D. A., Wooldridge, P. J., and Cohen, R. C.: Observations of the effects of temperature on atmospheric $\mathrm{HNO}_{3}, \Sigma \mathrm{ANs}, \Sigma \mathrm{PNs}$, and $\mathrm{NO}_{\mathrm{x}}$ : evidence for a temperature-dependent $\mathrm{HO}_{\mathrm{x}}$ source, Atmos. Chem. Phys., 8, 1867-1879, doi:10.5194/acp-8-1867-2008, 2008.

Day, D. A., Wooldridge, P. J., Dillon, M. B., Thornton, J. A., and Cohen, R. C.: A thermal dissociation laser-induced fluorescence instrument for in situ detection of $\mathrm{NO}_{2}$, peroxy nitrates, alkyl nitrates, and $\mathrm{HNO}_{3}$, J. Geophys. Res.-Atmos., 107, ACH 4-1ACH 4-14, doi:10.1029/2001jd000779, 2002.

DeCarlo, P. F., Kimmel, J. R., Trimborn, A., Northway, M. J., Jayne, J. T., Aiken, A. C., Gonin, M., Fuhrer, K., Horvath, T., Docherty, 
K. S., Worsnop, D. R., and Jimenez, J. L.: Field-deployable, high-resolution, time-of-flight aerosol mass spectrometer, Anal. Chem., 78, 8281-8289, doi:10.1021/ac061249n, 2006.

DeMott, P. J. and Prenni, A. J.: New Directions: Need for defining the numbers and sources of biological aerosols acting as ice nuclei, Atmos. Environ., 44, 1944-1945, doi:10.1016/j.atmosenv.2010.02.032, 2010.

DeMott, P. J., Prenni, A. J., Liu, X., Kreidenweis, S. M., Petters, M. D., Twohy, C. H., Richardson, M. S., Eidhammer, T., and Rogers, D. C.: Predicting global atmospheric ice nuclei distributions and their impacts on climate, P. Natl. USA, 107, 1121711222, doi:10.1073/pnas.0910818107, 2010.

Denman, K. L., Brasseur, G., Chidthaisong, A., Ciais, P., Cox, P. M., Dickinson, R. E., Hauglustaine, D., Heinze, C., Holland, E., Jacob, D., Lohmann, U., Ramachandran, S., da Silva Dias, P. L., Wofsy, S. C., and Zhang, X.: Couplings Between Changes in the Climate System and Biogeochemistry, in: Climate Change 2007: The Physical Science Basis. Contribution of Working Group I to the Fourth Assessment Report of the Intergovernmental Panel on Climate Change, edited by: Solomon, S., Qin, D., Manning, M., Chen, Z., Marquis, M., Averyt, K. B., Tignor, M., and Miller, H. L., Cambridge University Press, Cambridge, United Kingdom and New York, NY, USA, 2007.

DiGangi, J. P., Boyle, E. S., Karl, T., Harley, P., Turnipseed, A., Kim, S., Cantrell, C., Maudlin III, R. L., Zheng, W., Flocke, F., Hall, S. R., Ullmann, K., Nakashima, Y., Paul, J. B., Wolfe, G. M., Desai, A. R., Kajii, Y., Guenther, A., and Keutsch, F. N.: First direct measurements of formaldehyde flux via eddy covariance: implications for missing in-canopy formaldehyde sources, Atmos. Chem. Phys., 11, 10565-10578, doi:10.5194/acp-1110565-2011, 2011.

DiGangi, J. P., Henry, S. B., Kammrath, A., Boyle, E. S., Kaser, L., Schnitzhofer, R., Graus, M., Turnipseed, A., Park, J-H., Weber, R. J., Hornbrook, R. S., Cantrell, C. A., Maudlin III, R. L., Kim, S., Nakashima, Y., Wolfe, G. M., Kajii, Y., Apel, E.C., Goldstein, A. H., Guenther, A., Karl, T., Hansel, A., and Keutsch, F. N.: Observations of glyoxal and formaldehyde as metrics for the anthropogenic impact on rural photochemistry, Atmos. Chem. Phys., 12, 9529-9543, doi:10.5194/acp-12-9529-2012, 2012.

Edwards, G. D., Cantrell, C. A., Stephens, S., Hill, B., Goyea, O., Shetter, R. E., Mauldin, R. L., Kosciuch, E., Tanner, D. J., and Eisele, F. L.: Chemical ionization mass spectrometer instrument for the measurement of tropospheric $\mathrm{HO}_{2}$ and $\mathrm{RO}_{2}$, Anal. Chem., 75, 5317-5327, doi:10.1021/ac034402b, 2003.

Elbert, W., Taylor, P. E., Andreae, M. O., and Pöschl, U.: Contribution of fungi to primary biogenic aerosols in the atmosphere: wet and dry discharged spores, carbohydrates, and inorganic ions, Atmos. Chem. Phys., 7, 4569-4588, doi:10.5194/acp-7-4569-2007, 2007.

Eller, A. S. D., Harley, P., and Monson, R. K.: Potential contribution of exposed resin to ecosystem emissions of monoterpenes, Atmos. Environ., 77, 440-444, 2013.

Farmer, D. K. and Cohen, R. C.: Observations of $\mathrm{HNO}_{3}, \Sigma \mathrm{AN}$, $\Sigma \mathrm{PN}$ and $\mathrm{NO}_{2}$ fluxes: evidence for rapid $\mathrm{HO}_{\mathrm{x}}$ chemistry within a pine forest canopy, Atmos. Chem. Phys., 8, 3899-3917, doi:10.5194/acp-8-3899-2008, 2008.

Fast, J. D., Gustafson, W. I., Easter, R. C., Zaveri, R. A., Barnard, J. C., Chapman, E. G., Grell, G. A., and Peckham, S. E.: Evolution of ozone, particulates, and aerosol direct radiative forcing in the vicinity of Houston using a fully coupled meteorologychemistry-aerosol model, J. Geophys. Res-Atmos., 111, D21305, doi:10.1029/2005jd006721, 2006.

Fornwalt, P. J., Kaufmann, M. R., and Stohlgren, T. J.: Impacts of mixed severity wildfire on exotic plants in a Colorado ponderosa pine-Douglas-fir forest, Biol. Invasions, 12, 2683-2695, doi:10.1007/s10530-009-9674-2, 2010.

Fry, J. L., Draper, D. C., Zarzana, K. J., Campuzano-Jost, P., Day, D. A., Jimenez, J. L., Brown, S. S., Cohen, R. C., Kaser, L., Hansel, A., Cappellin, L., Karl, T., Hodzic Roux, A., Turnipseed, A., Cantrell, C., Lefer, B. L., and Grossberg, N.: Observations of gas- and aerosol-phase organic nitrates at BEACHON-RoMBAS 2011, Atmos. Chem. Phys., 13, 8585-8605, doi:10.5194/acp-138585-2013, 2013.

Gary, H. L.: A summary of research at the Manitou Experimental Forest in Colorado, 1937-1983, US Department of Agriculture, Forest Service Publication, Rocky Mountain Forest and Range Experiment Station, Fort Collins, CO, 1985.

Geron, C.: Carbonaceous aerosol over a Pinus taeda forest in Central North Carolina, USA, Atmos. Environ., 43, 959-969, doi:10.1016/j.atmosenv.2008.10.053, 2009.

Geron, C.: Carbonaceous aerosol characteristics over a Pinus taeda plantation: Results from the CELTIC experiment, Atmos. Environ., 45, 794-801, doi:10.1016/j.atmosenv.2010.07.015, 2011.

Greenberg, J. P., Asensio, D., Turnipseed, A., Guenther, A. B., Karl, T., and Gochis, D.: Contribution of leaf and needle litter to whole ecosystem BVOC fluxes, Atmos. Environ., 59, 302-311, doi:10.1016/j.atmosenv.2012.04.038, 2012.

Grell, G. A., Peckham, S. E., Schmitz, R., McKeen, S. A., Frost, G., Skamarock, W. C., and Elder, B.: Fully coupled "online" chemistry within the WRF model, Atmos. Environ., 39, 6957-6975, doi:10.1016/j.atmosenv.2005.04.027, 2005.

Guenther, A., Kulmala, M., Turnipseed, A., Rinne, J., Suni, T., and Reissell, A.: Integrated land ecosystem-atmosphere processes study (iLEAPS) assessment of global observational networks, Boreal Environ. Res., 16, 321-336, 2011.

Gunthe, S. S., King, S. M., Rose, D., Chen, Q., Roldin, P., Farmer, D. K., Jimenez, J. L., Artaxo, P., Andreae, M. O., Martin, S. T., and Pöschl, U.: Cloud condensation nuclei in pristine tropical rainforest air of Amazonia: size-resolved measurements and modeling of atmospheric aerosol composition and CCN activity, Atmos. Chem. Phys., 9, 7551-7575, doi:10.5194/acp-9-75512009, 2009.

Harley, P., Fridd-Stroud, V., Greenberg, J., Guenther, A., and Vasconcellos, P.: Emission of 2-methyl-3-buten-2-ol by pines: A potentially large natural source of reactive carbon to the atmosphere, J. Geophys. Res.-Atmos., 103, 25479-25486, doi:10.1029/98jd00820, 1998.

Heald, C. L., Wilkinson, M. J., Monson, R. K., Alo, C. A., Wang, G. L., and Guenther, A.: Response of isoprene emission to ambient $\mathrm{CO}_{2}$ changes and implications for global budgets, Glob. Change Biol., 15, 1127-1140, doi:10.1111/j.1365-2486.2008.01802.x, 2009.

Hodzic, A. and Jimenez, J. L.: Modeling anthropogenically controlled secondary organic aerosols in a megacity: a simplified framework for global and climate models, Geosci. Model Dev., 4, 901-917, doi:10.5194/gmd-4-901-2011, 2011.

Hofzumahaus, A., Rohrer, F., Lu, K. D., Bohn, B., Brauers, T., Chang, C. C., Fuchs, H., Holland, F., Kita, K., Kondo, Y., Li, 
X., Lou, S. R., Shao, M., Zeng, L. M., Wahner, A., and Zhang, Y. H.: Amplified Trace Gas Removal in the Troposphere, Science, 324, 1702-1704, doi:10.1126/science.1164566, 2009.

Hornbrook, R. S., Crawford, J. H., Edwards, G. D., Goyea, O., Mauldin III, R. L., Olson, J. S., and Cantrell, C. A.: Measurements of tropospheric $\mathrm{HO}_{2}$ and $\mathrm{RO}_{2}$ by oxygen dilution modulation and chemical ionization mass spectrometry, Atmos. Meas. Tech., 4, 735-756, doi:10.5194/amt-4-735-2011, 2011.

Hottle, J. R., Huisman, A. J., Digangi, J. P., Kammrath, A., Galloway, M. M., Coens, K. L., and Keutsch, F. N.: A Laser Induced Fluorescence-Based Instrument for In-Situ Measurements of Atmospheric Formaldehyde, Environ. Sci. Technol., 43, 790-795, doi:10.1021/es801621f, 2009.

Huffman, J. A., Prenni, A. J., DeMott, P. J., Pöhlker, C., Mason, R. H., Robinson, N. H., Fröhlich-Nowoisky, J., Tobo, Y., Després, V. R., Garcia, E., Gochis, D. J., Harris, E., Müller-Germann, I., Ruzene, C., Schmer, B., Sinha, B., Day, D. A., Andreae, M. O., Jimenez, J. L., Gallagher, M., Kreidenweis, S. M., Bertram, A. K., and Pöschl, U.: High concentrations of biological aerosol particles and ice nuclei during and after rain, Atmos. Chem. Phys., 13, 6151-6164, doi:10.5194/acp-13-6151-2013, 2013.

Huisman, A. J., Hottle, J. R., Coens, K. L., DiGangi, J. P., Galloway, M. M., Kammrath, A., and Keutsch, F. N.: Laserinduced phosphorescence for the in situ detection of glyoxal at part per trillion mixing ratios, Anal. Chem., 80, 5884-5891, doi:10.1021/ac800407b, 2008.

Jaatinen, A., Hamed, A., Joutsensaari, J., Mikkonen, S., Birmili, W., Wehner, B., Spindler, G., Wiedensohler, A., Decesari, S., Mircea, M., Facchini, M. C., Junninen, H., Kulmala, M., Lehtinen, K. E. J., and Laaksonen, A.: A comparison of new particle formation events in the boundary layer at three different sites in Europe, Boreal Environ. Res., 14, 481-498, 2009.

Jones, A. M. and Harrison, R. M.: The effects of meteorological factors on atmospheric bioaerosol concentrations - a review, Sci. Total Environ., 326, 151-180, doi:10.1016/j.scitotenv.2003.11.021, 2004.

Karl, T., Potosnak, M., Guenther, A., Clark, D., Walker, J., Herrick, J. D., and Geron, C.: Exchange processes of volatile organic compounds above a tropical rain forest: Implications for modeling tropospheric chemistry above dense vegetation, J. Geophys. Res.-Atmos., 109, D18306, doi:10.1029/2004jd004738, 2004.

Karl, T., Hansel, A., Cappellin, L., Kaser, L., Herdlinger-Blatt, I., and Jud, W.: Selective measurements of isoprene and 2methyl-3-buten-2-ol based on $\mathrm{NO}^{+}$ionization mass spectrometry, Atmos. Chem. Phys., 12, 11877-11884, doi:10.5194/acp12-11877-2012, 2012.

Karl, T., Kaser, L., and Turnipseed, A.: Eddy covariance measurements of isoprene and 232-MBO based on $\mathrm{NO}+$ time-of-flight mass spectrometry, Int. J. Mass Spectrom., 365-366, 15-19, 2014.

Kaser, L., Karl, T., Schnitzhofer, R., Graus, M., Herdlinger-Blatt, I. S., DiGangi, J. P., Sive, B., Turnipseed, A., Hornbrook, R. S., Zheng, W., Flocke, F. M., Guenther, A., Keutsch, F. N., Apel, E., and Hansel, A.: Comparison of different real time VOC measurement techniques in a ponderosa pine forest, Atmos. Chem. Phys., 13, 2893-2906, doi:10.5194/acp-13-2893-2013, 2013a.

Kaser, L., Karl, T., Guenther, A., Graus, M., Schnitzhofer, R., Turnipseed, A., Fischer, L., Harley, P., Madronich, M., Gochis, D., Keutsch, F. N., and Hansel, A.: Undisturbed and disturbed above canopy ponderosa pine emissions: PTR-TOF-MS measurements and MEGAN 2.1 model results, Atmos. Chem. Phys., 13, 11935-11947, doi:10.5194/acp-13-11935-2013, 2013b.

Kim, S., Wolfe, G. M., Mauldin, L., Cantrell, C., Guenther, A., Karl, T., Turnipseed, A., Greenberg, J., Hall, S. R., Ullmann, K., Apel, E., Hornbrook, R., Kajii, Y., Nakashima, Y., Keutsch, F. N., DiGangi, J. P., Henry, S. B., Kaser, L., Schnitzhofer, R., Graus, M., Hansel, A., Zheng, W., and Flocke, F. F.: Evaluation of $\mathrm{HO}_{\mathrm{x}}$ sources and cycling using measurement-constrained model calculations in a 2-methyl-3-butene-2-ol (MBO) and monoterpene (MT) dominated ecosystem, Atmos. Chem. Phys., 13, 20312044, doi:10.5194/acp-13-2031-2013, 2013.

Kirkby, J., Curtius, J., Almeida, J., Dunne, E., Duplissy, J., Ehrhart, S., Franchin, A., Gagne, S., Ickes, L., Kurten, A., Kupc, A., Metzger, A., Riccobono, F., Rondo, L., Schobesberger, S., Tsagkogeorgas, G., Wimmer, D., Amorim, A., Bianchi, F., Breitenlechner, M., David, A., Dommen, J., Downard, A., Ehn, M., Flagan, R. C., Haider, S., Hansel, A., Hauser, D., Jud, W., Junninen, H., Kreissl, F., Kvashin, A., Laaksonen, A., Lehtipalo, K., Lima, J., Lovejoy, E. R., Makhmutov, V., Mathot, S., Mikkila, J., Minginette, P., Mogo, S., Nieminen, T., Onnela, A., Pereira, P., Petaja, T., Schnitzhofer, R., Seinfeld, J. H., Sipila, M., Stozhkov, Y., Stratmann, F., Tome, A., Vanhanen, J., Viisanen, Y., Vrtala, A., Wagner, P. E., Walther, H., Weingartner, E., Wex, H., Winkler, P. M., Carslaw, K. S., Worsnop, D. R., Baltensperger, U., and Kulmala, M.: Role of sulphuric acid, ammonia and galactic cosmic rays in atmospheric aerosol nucleation, Nature, 476, 429-U477, doi:10.1038/nature10343, 2011.

Kleindienst, T. E., Jaoui, M., Lewandowski, M., Offenberg, J. H., Lewis, C. W., Bhave, P. V., and Edney, E. O.: Estimates of the contributions of biogenic and anthropogenic hydrocarbons to secondary organic aerosol at a southeastern US location, Atmos. Environ., 41, 8288-8300, doi:10.1016/j.atmosenv.2007.06.045, 2007.

Korhonen, H., Lehtinen, K. E. J., and Kulmala, M.: Multicomponent aerosol dynamics model UHMA: model development and validation, Atmos. Chem. Phys., 4, 757-771, doi:10.5194/acp-4757-2004, 2004.

Kulmala, M., Riipinen, I., Sipila, M., Manninen, H. E., Petaja, T., Junninen, H., Dal Maso, M., Mordas, G., Mirme, A., Vana, M., Hirsikko, A., Laakso, L., Harrison, R. M., Hanson, I., Leung, C., Lehtinen, K. E. J., and Kerminen, V. M.: Toward direct measurement of atmospheric nucleation, Science, 318, 89-92, doi:10.1126/science.1144124, 2007.

Kurpius, M. R. and Goldstein, A. H.: Gas-phase chemistry dominates O-3 loss to a forest, implying a source of aerosols and hydroxyl radicals to the atmosphere, Geophys. Res. Lett., 30, 1371, doi:10.1029/2002g1016785, 2003.

Lelieveld, J., Butler, T. M., Crowley, J. N., Dillon, T. J., Fischer, H., Ganzeveld, L., Harder, H., Lawrence, M. G., Martinez, M., Taraborrelli, D., and Williams, J.: Atmospheric oxidation capacity sustained by a tropical forest, Nature, 452, 737-740, doi:10.1038/nature06870, 2008

Levin, E. J. T., Prenni, A. J., Petters, M. D., Kreidenweis, S. M., Sullivan, R. C., Atwood, S. A., Ortega, J., DeMott, P. J., and Smith, J. N.: An annual cycle of size-resolved aerosol hygroscopicity at a forested site in Colorado, J. Geophys. Res-Atmos., 117, D06201, doi:10.1029/2011jd016854, 2012. 
Levin, E. J. T., Prenni, A. J., Palm, B. B., Day, D. A., CampuzanoJost, P., Winkler, P. M., Kreidenweis, S. M., DeMott, P. J., Jimenez, J. L., and Smith, J. N.: Size-resolved aerosol composition and its link to hygroscopicity at a forested site in Colorado, Atmos. Chem. Phys., 14, 2657-2667, doi:10.5194/acp-14-26572014, 2014.

Lewandowski, M., Piletic, I. R., Kleindienst, T. E., Offenberg, J. H., Beaver, M. R., Jaoui, M., Docherty, K. S., and Edney, E. O.: Secondary organic aerosol characterisation at field sites across the United States during the spring-summer period, Int. J. Environ. An. Ch., 93, 1084-1103, doi:10.1080/03067319.2013.803545, 2013.

Lewis, C. W., Klouda, G. A., and Ellenson, W. D.: Radiocarbon measurement of the biogenic contribution to summertime PM-2.5 ambient aerosol in Nashville, TN, Atmos. Environ., 38, 6053-6061, doi:10.1016/j.atmosenv.2004.06.011, 2004.

Lezberg, A. L., Battaglia, M. A., Shepperd, W. D., and Schoettle, A. W.: Decades-old silvicultural treatments influence surface wildfire severity and post-fire nitrogen availability in a ponderosa pine forest, Forest Ecol. Manag., 255, 49-61, doi:10.1016/j.foreco.2007.08.019, 2008.

Linkhart, B. D. and Reynolds, R. T.: Lifetime reproduction of Flammulated Owls in Colorado, J. Raptor Res., 40, 29-37, doi:10.3356/0892-1016(2006)40[29:Irofoi]2.0.co;2, 2006.

Linkhart, B. D. and Reynolds, R. T.: Return rate, fidelity, and dispersal in a breeding population of flammulated owls (Otus flammeolus), Auk, 124, 264-275, doi:10.1642/00048038(2007)124[264:rrfadi]2.0.co;2, 2007.

Mahowald, N., Ward, D. S., Kloster, S., Flanner, M. G., Heald, C. L., Heavens, N. G., Hess, P. G., Lamarque, J. F., and Chuang, P. Y.: Aerosol Impacts on Climate and Biogeochemistry, Annu. Rev. Env. Resour., 36, 45-74, doi:10.1146/annurevenviron-042009-094507, 2011.

Mao, J., Ren, X., Zhang, L., Van Duin, D. M., Cohen, R. C., Park, J.-H., Goldstein, A. H., Paulot, F., Beaver, M. R., Crounse, J. D., Wennberg, P. O., DiGangi, J. P., Henry, S. B., Keutsch, F. N., Park, C., Schade, G. W., Wolfe, G. M., Thornton, J. A., and Brune, W. H.: Insights into hydroxyl measurements and atmospheric oxidation in a California forest, Atmos. Chem. Phys., 12, 8009-8020, doi:10.5194/acp-12-8009-2012, 2012.

Massman, W. J., Frank, J. M., and Mooney, S. J.: Advancing investigation and physical modeling of first-order fire effects on soils, Fire Ecology, 6, 36-54, doi:10.4996/fireecology.0601036, 2010.

Matsui, H., Koike, M., Kondo, Y., Takegawa, N., Wiedensohler, A., Fast, J. D., and Zaveri, R. A.: Impact of new particle formation on the concentrations of aerosols and cloud condensation nuclei around Beijing, J. Geophys. Res.-Atmos., 116, D19208, doi:10.1029/2011jd016025, 2011.

Mauldin, R. L., Eisele, F. L., Cantrell, C. A., Kosciuch, E., Ridley, B. A., Lefer, B., Tanner, D. J., Nowak, J. B., Chen, G., Wang, L., and Davis, D.: Measurements of OH aboard the NASA P-3 during PEM-Tropics B, J. Geophys. Res.-Atmos., 106, 3265732666, doi:10.1029/2000jd900832, 2001.

Mirme, S., Mirme, A., Minikin, A., Petzold, A., Hõrrak, U., Kerminen, V. -M., and Kulmala, M.: Atmospheric sub-3 nm particles at high altitudes, Atmos. Chem. Phys., 10, 437-451, doi:10.5194/acp-10-437-2010, 2010.

Morris, C. E., Conen, F., Huffman, J. A., Phillips, V., Pöschl, U., and Sands, D. C.: Bioprecipitation: A feedback cycle linking Earth history, ecosystem dynamics and land use through biological ice nucleators in the atmosphere, Global Change Biol., 20, 341-351, doi:10.1111/gcb.12447, 2013.

Moteki, N., Kondo, Y., and Nakamura, S.: Method to measure refractive indices of small nonspherical particles: Application to black carbon particles, J. Aerosol. Sci., 41, 513-521, 2010.

Orlando, J. J. and Tyndall, G. S.: Laboratory studies of organic peroxy radical chemistry: an overview with emphasis on recent issues of atmospheric significance, Chem. Soc. Rev., 41, 82138213, 2012.

Paasonen, P., Asmi, A., Petaja, T., Kajos, M. K., Aijala, M., Junninen, H., Holst, T., Abbatt, J. P. D., Arneth, A., Birmili, W., van der Gon, H. D., Hamed, A., Hoffer, A., Laakso, L., Laaksonen, A., Leaitch, W. R., Plass-Dulmer, C., Pryor, S. C., Raisanen, P., Swietlicki, E., Wiedensohler, A., Worsnop, D. R., Kerminen, V. M., and Kulmala, M.: Warming-induced increase in aerosol number concentration likely to moderate climate change, Nat. Geosci., 6, 438-442, doi:10.1038/ngeo1800, 2013.

Peeters, J., Nguyen, T. L., and Vereecken, L.: $\mathrm{HO}_{\mathrm{x}}$ radical regeneration in the oxidation of isoprene, Phys. Chem. .Chem. Phys., 11, 5935-5939, 10.1039/b908511d, 2009.

Petters, M. D. and Kreidenweis, S. M.: A single parameter representation of hygroscopic growth and cloud condensation nucleus activity, Atmos. Chem. Phys., 7, 1961-1971, doi:10.5194/acp-71961-2007, 2007.

Pöhlker, C., Wiedemann, K. T., Sinha, B., Shiraiwa, M., Gunthe, S. S., Smith, M., Su, H., Artaxo, P., Chen, Q., Cheng, Y. F., Elbert, W., Gilles, M. K., Kilcoyne, A. L. D., Moffet, R. C., Weigand, M., Martin, S. T., Poeschl, U., and Andreae, M. O.: Biogenic Potassium Salt Particles as Seeds for Secondary Organic Aerosol in the Amazon, Science, 337, 10751078, doi:10.1126/science.1223264, 2012.

Pöschl, U., Martin, S. T., Sinha, B., Chen, Q., Gunthe, S. S., Huffman, J. A., Borrmann, S., Farmer, D. K., Garland, R. M., Helas, G., Jimenez, J. L., King, S. M., Manzi, A., Mikhailov, E., Pauliquevis, T., Petters, M. D., Prenni, A. J., Roldin, P., Rose, D., Schneider, J., Su, H., Zorn, S. R., Artaxo, P., and Andreae, M. O.: Rainforest Aerosols as Biogenic Nuclei of Clouds and Precipitation in the Amazon, Science, 329, 15131516, doi:10.1126/science.1191056, 2010.

Prenni, A. J., Tobo, Y., Garcia, E., DeMott, P. J., Huffman, J. A., McCluskey, C. S., Kreidenweis, S. M., Prenni, J. E., Pohlker, C., and Poschl, U.: The impact of rain on ice nuclei populations at a forested site in Colorado, Geophys. Res. Lett., 40, 227-231, doi:10.1029/2012g1053953, 2013.

Pryor, S. C., Barthelmie, R. J., and Hornsby, K. E.: Size-resolved particle fluxes and vertical gradients over and in a sparse pine forest, Aerosol Sci. Tech., 47, 1248-1257, 2013.

Pryor, S. C., Spaulding, A. M., and Barthelmie, R. J.: New particle formation in the Midwestern USA: Event characteristics, meteorological context and vertical profiles, Atmos. Environ., 44, 4413-4425, doi:10.1016/j.atmosenv.2010.07.045, 2010.

Rhoades, C. C., Battaglia, M. A., Rocca, M. E., and Ryan, M. G.: Short- and medium-term effects of fuel reduction mulch treatments on soil nitrogen availability in Colorado conifer forests, Forest Ecol. Manag., 276, 231-238, doi:10.1016/j.foreco.2012.03.028, 2012.

Rollins, A. W., Smith, J. D., Wilson, K. R., and Cohen, R. C.: Real Time In Situ Detection of Organic Nitrates in At- 
mospheric Aerosols, Environ. Sci. Technol., 44, 5540-5545, doi:10.1021/es100926x, 2010.

Schobesberger, S., Vaananen, R., Leino, K., Virkkula, A., Backman, J., Pohja, T., Siivola, E., Franchin, A., Mikkila, J., Paramonov, M., Aalto, P. P., Krejci, R., Petaja, T., and Kulmala, M.: Airborne measurements over the boreal forest of southern Finland during new particle formation events in 2009 and 2010, Boreal Environ. Res., 18, 145-163, 2013.

Schumacher, C. J., Pöhlker, C., Aalto, P., Hiltunen, V., Petäjä, T., Kulmala, M., Pöschl, U., and Huffman, J. A.: Seasonal cycles of fluorescent biological aerosol particles in boreal and semiarid forests of Finland and Colorado, Atmos. Chem. Phys., 13, 11987-12001, doi:10.5194/acp-13-11987-2013, 2013.

Shrivastava, M., Fast, J., Easter, R., Gustafson Jr., W. I., Zaveri, R. A., Jimenez, J. L., Saide, P., and Hodzic, A.: Modeling organic aerosols in a megacity: comparison of simple and complex representations of the volatility basis set approach, Atmos. Chem. Phys., 11, 6639-6662, doi:10.5194/acp-11-6639-2011, 2011.

Soil Conservation Service: Soil Survey of Pike National Forest, Eastern Part, Colorado, Parts of Douglas, El Paso, Jefferson and Teller Counties. United States Department of Agriculture, Forest Service and Soil Conservation Service, 106 pp., 1992.

Stone, D., Whalley, L. K., and Heard, D. E.: Tropospheric OH and $\mathrm{HO}_{2}$ radicals: field measurements and model comparisons, Chem. Soc. Rev., 41, 6348-6404, 10.1039/c2cs35140d, 2012.

Thornton, J. A., Wooldridge, P. J., Cohen, R. C., Martinez, M., Harder, H., Brune, W. H., Williams, E. J., Roberts, J. M., Fehsenfeld, F. C., Hall, S. R., Shetter, R. E., Wert, B. P., and Fried, A.: Ozone production rates as a function of $\mathrm{NO}_{\mathrm{X}}$ abundances and $\mathrm{HO}_{\mathrm{x}}$ production rates in the Nashville urban plume, J. Geophys. Res., 107, 4146-4163, doi:10.1029/2001JD000932, 2002.

Tobo, Y., Prenni, A. J., DeMott, P. J., Huffman, J. A., McCluskey, C. S., Tian, G., Pöhlker, C., Pöschl, U., Kreidenweis, S. M.: Biological aerosol particles as a key determinant of ice nuclei populations in a forest ecosystem, J. Geophys. Res-Atmos., 118, 1010010110, doi:10.1002/jgrd.50801, 2013.

Vorosmarty, C. J., McIntyre, P. B., Gessner, M. O., Dudgeon, D., Prusevich, A., Green, P., Glidden, S., Bunn, S. E., Sullivan, C. A., Liermann, C. R., and Davies, P. M.: Global threats to human water security and river biodiversity, Nature, 467, 555-561, doi:10.1038/nature09440, 2010.

Williams, B. J., Jayne, J. T., Lambe, A. T., Hohaus, T., Kimmel, J. R., Sueper, D., Brooks, W., Williams,.L. R., Trimborn, A. M., Martinez, R. E., Hayes,.P. L., Jimenez, J. L., Kreisberg, N. M., Hering, S. V., Worton, D. R., Goldstein, A. H., and Worsnop, D. R.: The First Combined Thermal Desorption Aerosol Gas Chromatograph - Aerosol Mass Spectrometer (TAG-AMS), Aerosol Sci. Tech., 48, 358370, doi:10.1080/02786826.2013.875114, 2014.
Wolfe, G. M., Thornton, J. A., Bouvier-Brown, N. C., Goldstein, A. H., Park, J.-H., McKay, M., Matross, D. M., Mao, J., Brune, W. H., LaFranchi, B. W., Browne, E. C., Min, K.-E., Wooldridge, P. J., Cohen, R. C., Crounse, J. D., Faloona, I. C., Gilman, J. B., Kuster, W. C., de Gouw, J. A., Huisman, A., and Keutsch, F. N.: The Chemistry of Atmosphere-Forest Exchange (CAFE) Model - Part 2: Application to BEARPEX-2007 observations, Atmos. Chem. Phys., 11, 1269-1294, doi:10.5194/acp-11-12692011, 2011.

Wolfe, G. M., Cantrell, C., Kim, S., Mauldin III, R. L., Karl, T., Harley, P., Turnipseed, A., Zheng, W., Flocke, F., Apel, E. C., Hornbrook, R. S., Hall, S. R., Ullmann, K., Henry, S. B., DiGangi, J. P., Boyle, E. S., Kaser, L., Schnitzhofer, R., Hansel, A., Graus, M., Nakashima, Y., Kajii, Y., Guenther, A., and Keutsch, F. N.: Missing peroxy radical sources within a summertime ponderosa pine forest, Atmos. Chem. Phys., 14, 4715-4732, doi:10.5194/acp-14-4715-2014, 2014.

Yatavelli, R. L. N., Lopez-Hilfiker, F., Wargo, J. D., Kimmel, J. R., Cubison, M. J., Bertram, T. H., Jimenez, J. L., Gonin, M., Worsnop, D. R., and Thornton, J. A.: A Chemical Ionization High-Resolution Time-of-Flight Mass Spectrometer Coupled to a Micro Orifice Volatilization Impactor (MOVI-HRToF-CIMS) for Analysis of Gas and Particle-Phase Organic Species, Aerosol Sci. Tech., 46, 1313-1327, doi:10.1080/02786826.2012.712236, 2012.

Yatavelli, R. L. N., Stark, H., Thompson, S. L., Kimmel, J. R., Cubison, M. J., Day, D. A., Campuzano-Jost, P., Palm, B. B., Hodzic, A., Thornton, J. A., Jayne, J. T., Worsnop, D. R., and Jimenez, J. L.: Semicontinuous measurements of gas-particle partitioning of organic acids in a ponderosa pine forest using a MOVI-HRToFCIMS, Atmos. Chem. Phys., 14, 1527-1546, doi:10.5194/acp14-1527-2014, 2014

Zhang, H. F., Worton, D. R., Lewandowski, M., Ortega, J., Rubitschun, C. L., Park, J. H., Kristensen, K., Campuzano-Jost, P., Day, D. A., Jimenez, J. L., Jaoui, M., Offenberg, J. H., Kleindienst, T. E., Gilman, J., Kuster, W. C., de Gouw, J., Park, C., Schade, G. W., Frossard, A. A., Russell, L., Kaser, L., Jud, W., Hansel, A., Cappellin, L., Karl, T., Glasius, M., Guenther, A., Goldstein, A. H., Seinfeld, J. H., Gold, A., Kamens, R. M., and Surratt, J. D.: Organosulfates as Tracers for Secondary Organic Aerosol (SOA) Formation from 2-Methyl-3-Buten-2-ol (MBO) in the Atmosphere, Environ. Sci. Technol., 46, $9437-$ 9446, doi:10.1021/es301648z, 2012.

Zhao, Y. L., Kreisberg, N. M., Worton, D. R., Teng, A. P., Hering, S. V., and Goldstein, A. H.: Development of an In Situ Thermal Desorption Gas Chromatography Instrument for Quantifying Atmospheric Semi-Volatile Organic Compounds, Aerosol Sci. Tech., 47, 258-266, doi:10.1080/02786826.2012.747673, 2013. 